\title{
Minimal Residual Disease, Metastasis and Immunity
}

\author{
Jordi Badia-Ramentol, Jenniffer Linares, Andrea Gómez-Llonin and Alexandre Calon *
}

Cancer Research Program, Hospital del Mar Medical Research Institute (IMIM), 08003 Barcelona, Spain; jbadia@imim.es (J.B.-R.); jlinares@imim.es (J.L.); agomez2@imim.es (A.G.-L.)

* Correspondence: acalon@imim.es

\section{check for}

updates

Citation: Badia-Ramentol, J.; Linares,

J.; Gómez-Llonin, A.; Calon, A.

Minimal Residual Disease, Metastasis and Immunity. Biomolecules 2021, 11,

130. https://doi.org/10.3390/

biom 11020130

Received: 18 December 2020

Accepted: 13 January 2021

Published: 20 January 2021

Publisher's Note: MDPI stays neutral with regard to jurisdictional claims in published maps and institutional affiliations.

Copyright: (c) 2021 by the authors. Licensee MDPI, Basel, Switzerland. This article is an open access article distributed under the terms and conditions of the Creative Commons Attribution (CC BY) license (https:/ / creativecommons.org/licenses/by/ $4.0 /)$.

\begin{abstract}
Progression from localized to metastatic disease requires cancer cells spreading to distant organs through the bloodstream. Only a small proportion of these circulating tumor cells (CTCs) survives dissemination due to anoikis, shear forces and elimination by the immune system. However, all metastases originate from CTCs capable of surviving and extravasating into distant tissue to re-initiate a tumor. Metastasis initiation is not always immediate as disseminated tumor cells (DTCs) may enter a non-dividing state of cell dormancy. Cancer dormancy is a reversible condition that can be maintained for many years without being clinically detectable. Subsequently, late disease relapses are thought to be due to cancer cells ultimately escaping from dormant state. Cancer dormancy is usually associated with minimal residual disease (MRD), where DTCs persist after intended curative therapy. Thus, MRD is commonly regarded as an indicator of poor prognosis in all cancers. In this review, we examine the current understanding of MRD and immunity during cancer progression to metastasis and discuss clinical perspectives for oncology.
\end{abstract}

Keywords: CTC; DTC; MRD; dormancy; immunity; metastasis; therapy

\section{The Circulating Tumor Cell}

At the onset of metastatic dissemination, cancer cells are released from the tumor of origin and intravasate into the bloodstream. These circulating tumor cells (CTCs) have to survive the environmental hazards posed by the circulatory and the immune system to successfully colonize distant organs, thus becoming disseminated tumor cells (DTCs). Invasive primary tumors are constantly shedding CTCs, which are indicative of minimal residual disease (MRD) that may persist after antitumor therapy. Nevertheless, only a small proportion of CTCs are capable of generating distant metastases, which makes metastatic dissemination an extremely inefficient process. Indeed, in a study in 2007, Nagrath and colleagues were able to isolate CTC from peripheral blood in more than $99 \%$ of patients with advanced disease. However, only a subset of positive patients actually developed metastases [1].

Many studies have uncovered processes that may lead to the generation and release of CTCs, with a special consideration to epithelial-mesenchymal transition (EMT) $[2,3]$. EMT is defined by the loss of epithelial hallmarks, cell-cell and cell-extracellular matrix adhesion features and gain of a mesenchymal-like transcriptional program [4]. EMT can be triggered by the TGF- $\beta$, WNT and NOTCH pathways and is mainly regulated by the transcription factors ZEB, SNAIL, SLUG and TWIST1 [5]. EMT is responsible for the acquisition of migratory and self-renewal traits in cancer cells, which are crucial for metastatic dissemination $[2,3,5,6]$. Indeed, multiple recent studies have reported the existence of stem cell-like CTCs expressing EMT markers such as Vimentin or N-cadherin and which are associated with metastatic potential and poor clinical outcome in various cancers [7-13].

Evidence suggests that polyclonal clusters of CTCs have increased metastatic potential compared to individual CTCs [14]. Indeed, CTC clustering increases stemness and proliferation by inducing hypomethylation of critical transcription factors such as OCT4, NANOG, 
SOX2 and SIN3A [15]. Although EMT has been generally linked to the shedding of single cells into the circulation, it can also provoke collective cell migration (CCM) of clusters from primary tumors. Using a model of metastatic intestinal carcinomas in Drosophila, Campbell and colleagues showed an association between Sna (the homolog of a human snail) -expressing clones undergoing EMT with clusters of cancer cells, which are able to collectively break through the basal lamina of the gut [16]. Results from this study confirmed previous findings using 3D in vitro models of tumor budding, where cancer cells with a gain of ZEB1 and loss of E-cadherin expression may drive collective rather than single-cell migration [17]. During CCM, single cells that undergo EMT exert mechanical forces that are transmitted throughout the neighboring cells within the cluster [18]. Nevertheless, effective CCM leans on the fact that most cancer cells in the cluster retain epithelial features such as tight junctions, which can be further regulated by Epigen-EGFR signaling occurring in the intercellular nanolumina between neighboring cancer cells [19-22]. Recent advances point to a key role of the Wnt/planar cell polarity (PCP) pathway driving CCM, where effector Rac1 and ROCK2 are major inducers of cell polarity [18,23,24]. Ultimately, Wnt/PCP activation leads to a RhoA-GTPase-dependent accumulation of RAB13 and NET1 mRNA in cancer cells at the invasive front, and triggers cell migration supported by changes in the ECM and laminin-5 accumulation [25-28]. Additional research has recently shown that cancer-associated fibroblasts (CAFs) facilitate CCM through heterotypic adhesions and cell-to-cell activation of Wnt and NOTCH pathways [29-34].

Once shed into the bloodstream, CTCs must overcome a series of hazards that may compromise their integrity and their capacity to generate distant metastases. Among them, flow speed, turbulence and a high density of circulating objects induce shear stress hindering CTC survival [35]. Individual CTC detachment from the ECM may also induce anoikis that can be overcome by tight junction maintenance in circulating clusters [36]. Several recent studies have shown that hyper-activated platelets adhere to CTC clusters and secrete soluble effectors conferring enhanced survival properties and increased metastatic efficiency to CTCs [37-40]. In this context, Yu and colleagues described that platelet-tumor cell interaction through Toll-like receptor 4 (TLR4) promotes tumor metastasis [41]. CTCs may also cluster with circulating neutrophils through VCAM1 expression, thus resulting in increased proliferation and migration of CTCs [42,43].

In addition to shearing forces, CTCs are under constant immuno-surveillance, especially from natural killer (NK) cells. Along this line, EMT induces overexpression of NK activator ligands NKG2DL, ULBP1-3 and MHC-I, and downregulation of CADM1, all of which confer increased susceptibility of CTCs to NK-mediated clearance [44,45]. In this scenario, hybrid clusters containing mesenchymal-like and epithelial CTCs are favored against individual CTCs that have undergone EMT, most likely due to NK cells' decreased sensitivity over cancer cells maintaining epithelial hallmarks [20].

\section{Mechanisms of CTC Extravasation into Secondary Organs}

Adhesion of CTCs to endothelial cells (ECs) is a first key step of the extravasation process. The initial attachment of tumor cells to the vessel endothelium depends on the expression of selectin family receptors by ECs such as E-selectin and P-selectin, which interact with their respective ligands expressed by cancer cells [46]. Selectin ligands include the tetrasaccharide sialyl-Lewis X antigen and its isomer sialyl-Lewis A [47]. Especially Sialyl-Lewis $\mathrm{X}$ and P-selectin interaction was shown to contribute to tumor-mesothelial adhesion and metastatic initiation [48]. In addition, CTCs can also locally enhance the expression of selectin through STAT3 pathway activation in ECs, thus increasing adherence to the endothelium [49].

Following attachment, stable adhesion and trans-endothelial migration (TEM) are achieved mainly through integrins and their ligands, including cell-adhesion molecules (CAM) $[50,51]$. Integrins are heterodimeric adhesion receptors that interact with both ECM and cell-surface ligands [52]. Integrins are key for progression to metastasis, as their decreased expression significantly reduces metastasis initiation [36]. During TEM, $\alpha 3 \beta 1$ 
and $\alpha 6 \beta 1$ integrins contribute to tumor cell adhesion to the sub-endothelial basement membrane in multiple cancers [53]. In breast cancer, for example, CTCs may undergo $\beta 1$ integrin-dependent adhesion and TEM by inducing vascular endothelium remodeling [54]. In addition, Aragon-Sanabria and colleagues proposed that intercellular adherent junctions' disassembly and endothelial cell contractility were necessary for endothelial barrier disruption, both being modulated by cancer cells originating signaling [55]. For instance, cancer-cell-secreted SPARC facilitates EC junction opening, thereby contributing to vascular permeability and paracellular TEM [56]. In this context, it has also been demonstrated that secreted factors from cancer cells may trigger focal adhesion protein (FAK)/E-selectin cascade in ECs to induce formation of vascular hyper-permeability foci in pre-metastatic lungs ECs [57].

As mentioned in the first section, CTCs may interact with platelets and leukocytes during metastatic dissemination. Interestingly, while a majority of CTCs are associated with different platelet coverage [58], cancer cell and platelet interactions mediate CTCs adhesion to ECs, thereby promoting tumor metastasis [46]. In addition, platelets may secrete factors contributing to vascular permeability [59] and cancer cell extravasation [60]. In this context, platelet-secreted TGF- $\beta$ induces cancer cells EMT, thus increasing their invasiveness and their ability to extravasate [61].

Alternatively, physical interplay between leukocytes and CTCs may also increase CTCs' capacity to adhere to the endothelium [58]. For instance, neutrophils increase tumor cell adhesion to hepatic sinusoidal ECs [62]. Moreover, neutrophils expressing $\beta 2$ integrin may also enhance CTC-EC adhesion by interacting with ICAM1 expressed by cancer cells and ECs in breast cancer [63]. Following initial adhesion, the interaction between $\alpha \mathrm{M} \beta 2$ integrin on neutrophils and ICAM1 on breast CTCs induces cancer cell TEM [64]. Finally, macrophages may also interact with CTCs to further assist them during extravasation [65]. For instance, macrophages may secrete tumor necrosis factor $\alpha$ (TNF- $\alpha$ ), which induces E-selectin expression by endothelial cells [66]. In this context, metastatic tumor cells may increase TNF- $\alpha$ secretion by Kupffer cells, thus leading to E-selectin, VCAM1 and PECAM1 expression in hepatic sinusoidal vessels [67].

\section{Organotropism and Metastatic Niche}

Organ specification for metastatic seeding can be determined by physical proximity to the tumor of origin. For example, L1CAM+ metastasis-initiating cells originating from colorectal carcinomas are more prone to invade the liver through portal circulation [3,68-70]. However, the determinants of metastatic site specification remain an open field of research, and alternative hypotheses suggest that CTCs may need intrinsic traits in order to thrive into specific metastatic loci. Several mechanisms depending on the expression of miR-105, L1CAM, MMP-2, COX2 and HB-EGF have been described for brain metastasis initiated by breast and lung originating CTCs [71-73]. Alternatively, expression of CXCR4 is required by breast cancer cells to metastasize into the bone [2,73], while lung metastasis originating from primary melanoma and breast tumors depends on ANGPTL4 and SPARC expression $[56,74]$. In addition, colorectal cancer (CRC)-derived metastasis grown in the liver can further metastasize to the lung through downregulation of p38 MAPK signaling and expression of PTHLH [75].

In order to successfully initiate metastases, DTCs must harbor stem cell-like properties of self-renewal and proliferation typical of "cancer stem cells" (CSCs). For instance, tumorinitiating cells are characterized by bona fide expression of normal stem cell markers such as LGR5 and EPHB2 in CRC [70,76-79]. Similarly, single cell analysis has shown that cancer cells in nascent metastases from breast primary tumor express a stem cell-like genetic program [80]. Therefore, DTCs may require paracrine signaling originating from the local environment to maintain stemness properties. In this aspect, the "seed and soil" hypothesis proposed by Stephen Paget in 1889 suggests that the foreign niche is key to metastatic initiation [81]. As a matter of fact, several studies have described that local and bone-marrow-derived cells are recruited during the colonization to provide factors 
activating stem-cell pathways such as TGF- $\beta$, BMP, Wnt, Notch and Stat3 in DTCs [2]. Alternatively, growing evidence supports the hypothesis of a pre-metastatic niche (PMN) assembled prior to organ colonization and controlled by primary tumor-secreted factors like exosomes. As reviewed elsewhere, exosomes may influence virtually every component of the PMN [82-85].

Fibroblasts are one of the key cellular components of the metastatic niche, where they are activated into cancer-associated fibroblasts (CAFs) by TGF- $\beta$ [86-89], FGF2 and members of the PDGF family [89]. Alternatively, IL- $1 \alpha$ and IL- $1 \beta$ secretion by metastasisinitiating breast cancer cells [90] may activate CAFs to secrete ECM-remodeling factors such as matrix metalloproteinases (MMPs), LOX enzymes, Periostin, Tenascin-C and Versican, among others, thus providing a favorable niche for organ colonization $[82,89,91]$. Additionally, CAFs provide a niche factor that maintains stem cell properties of metastatic initiating cells, including but not limited to CXCL9, CXCL10 [90], CXCL12 [92], IL-11 [86], TGF- $\beta 1$ [93], HGF [94], CCL18, Osteopontin and plasminogen activator inhibitor 1 [95]. Interestingly, several studies have reported the existence of several CAF subpopulations with functional differences coexisting within a tumor, including defined populations that promote stemness. For instance, $\alpha \mathrm{SMA}+\mathrm{CAFs}$ in oral cancer are positively correlated with the presence of CSCs [96]. Similarly, NF-кB expression in CD10+GPR77+ CAFs from breast and lung cancers maintains stem cell properties of cancer cells through secretion of IL-6 and IL-8 [97]. Finally, both CAFs and metastatic initiating cells may recruit immune cells such as myeloid-derived suppressor cells (MDSCs), macrophages and neutrophils, which in turn support CTC survival and organ colonization by establishing a permissive immunosuppressive environment [98-105].

\section{The Metastatic Dormant Cell}

Tumor dormancy refers to a transient growth and mitotic arrest occurring in cancer cells (see Figure 1). This phenomenon is critical for the establishment of a resistant MRD that may lead to tumor relapses years after therapy [106,107]. Dormancy that usually occurs during the formation of tumors or after dissemination to distant organs enables DTCs to adapt to and colonize distant organs [108]. In this sense, several distinct mechanisms have been proposed to maintain single cell dormancy and dormant micrometastases, which include angiogenic dormancy, intrinsic or extrinsic cellular dormancy and immunemediated dormancy [109].

The expansion of micrometastatic lesions is at first restricted by similar rates of cancer cell proliferation and apoptosis, primarily due to poor vascularization. Several studies have reported that molecules such as thrombospondin (TSP), vascular endothelial growth factor (VEGF) and epoxyeicosatrienoic acids (EETs) expressed by ECs in the stable microvasculature might influence tumor angiogenesis, which consequently regulates the maintenance of DTCs dormancy or their switch into a proliferative state [110-113]. Similarly, the recruitment of vascular and myeloid cells by secreted tissue factor (TF) has been shown to modulate cancer cells dormancy in glioma cells [114].

DTCs can also activate self-imposed intrinsic dormancy programs (see Figure 1), for example, by F-box/WD repeat-containing protein 7 (FBXW7) and the leukemia inhibitory factor receptor (LIFR), which allow them to adapt to new microenvironments and remain unaffected by therapies targeting highly proliferative cells $[115,116]$. DTCs can also alter signaling pathways that coordinate metabolic homeostasis, such as the PI3K-AKT pathway $[117,118]$. In addition, autophagy-related 7 (ATG7) has also been involved in survival of dormant breast cancer cells [119]. Finally, latent breast and lung carcinoma cells may express stem cell-like SOX transcription factors, which self-impose a slow proliferating state [120]. 

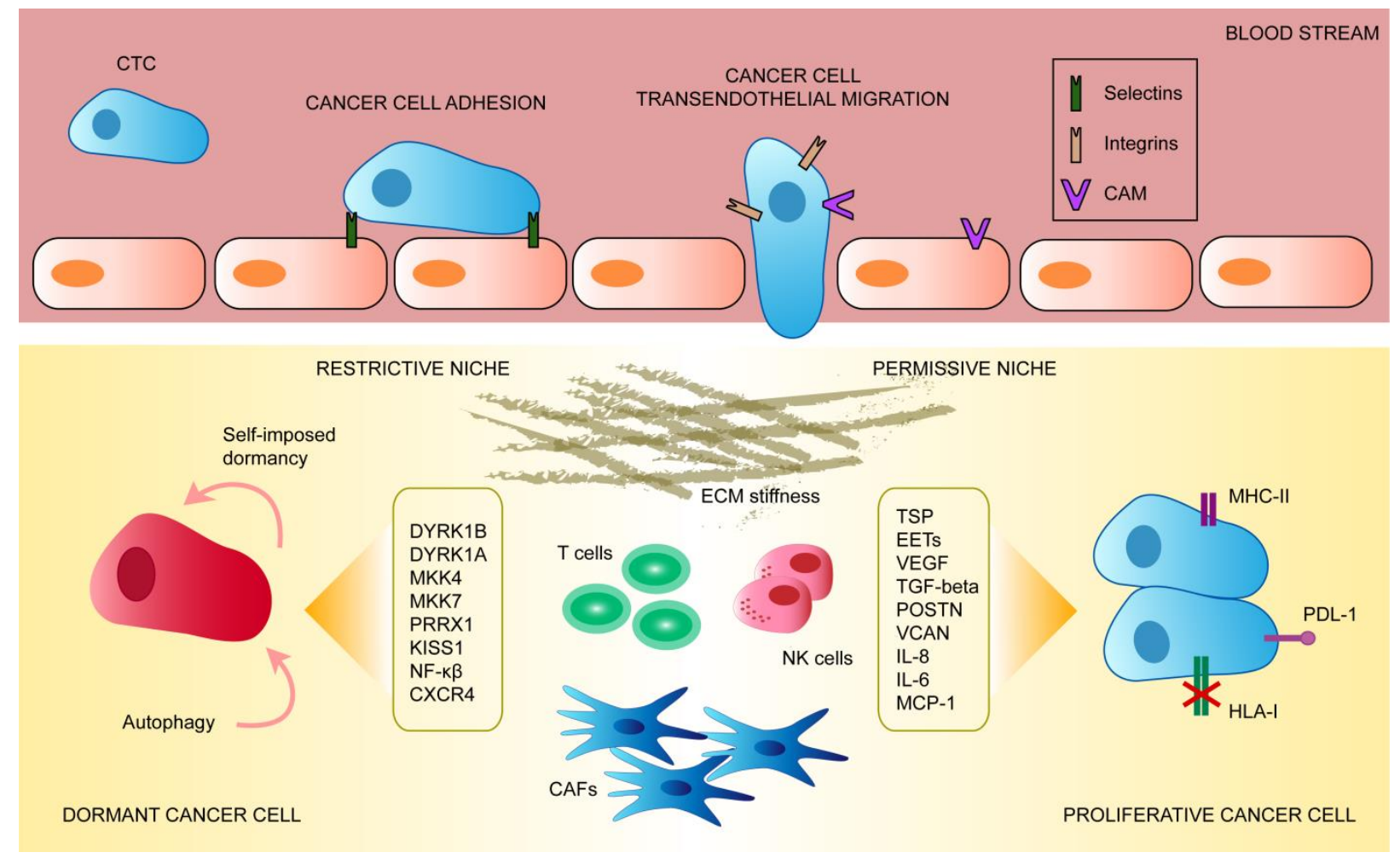

Figure 1. In order to colonize distant organs, circulating cancer cells will eventually adhere and transmigrate through the endothelium thanks to the expression of different ligands and receptors. Following trans-endothelial migration, cancer cells will either enter a dormant or a proliferative state. Disseminated cancer cells' dormancy or proliferation is determined by both intrinsic signaling and cues originating from the surrounding restrictive or permissive niche.

Alternatively, cellular dormancy may occur through extrinsic mechanisms (see Figure 1), and the differential ability of organs to support DTC growth has led to the classification of microenvironments as dormancy-permissive or dormancy-restrictive [121-123]. Indeed, local microenvironment-originating stress signals have been proposed to induce DTC dormancy, including specific kinases such as dual specificity tyrosine phosphorylation-regulated kinase $1 \mathrm{~B}$ (DYRK1B) and 1A (DYRK1A), mitogen-activated kinases such as MKK4 (MAPKK4) and MKK7, paired-related homeobox transcription factor (PRRX1), kisspeptin 1 (KISS1), downregulation of the C-X-C motif chemokine receptor 4 (CXCR4) and the activation of the canonical nuclear factor kappa-light-chain enhancer of activated B cells (NF-kB) pathway [124-135]. Moreover, early studies showed that ECM protein fibronectin (FN) may determine whether DTCs can remain in a dormant state by interacting with the urokinase plasminogen activator receptor (uPAR) in cancer cells. Indeed, high levels of uPAR increase adhesion of cells to fibronectin and generate persistent activation of ERK, which is necessary for tumor growth [136,137].

Finally, DTCs dormancy may also depend on an equilibrium state with the immune surveillance system [138], exerted mainly by tumor-infiltrating lymphocytes (TILs) and NK cells and mainly regulated by the secretion of interferon gamma (IFN $\gamma$ ) [138-141]. In this setting, the immune system may regulate DTC numbers and micrometastatic lesion size [142]. For instance, an increased density of immune cells has been observed in the bone marrow of patients with breast cancer displaying dormant DTCs [143]. In this line, CD4+ and CD8+ T cell depletion in vivo resulted in cancer cells escaping from dormancy [120,144]. Furthermore, the action of NK and T cells can be regulated by tumor cells on the basis of HLA class I expression. Therefore, variations in the expression of these proteins in DTCs are key to NK and T cells' cytotoxic response and dormancy maintenance $[145,146]$. 


\section{Escape from Dormancy and Immune Evasion}

Escape from dormancy is often directed by intrinsic changes of gene expression patterns in DTCs. Alternatively, it may also depend on certain traits and interactions with the host tissue (see Figure 1). The secretion of soluble factors, including interleukin-8 (IL-8) and monocyte chemoattractant protein-1 (MCP-1) by cancer cells has been shown to promote breast cancer cells proliferation [147]. Upregulation and activation of the vascular cell adhesion protein 1 (VCAM1) and periostin (POSTN) may induce escape from dormancy $[112,148]$. In addition, increased matrix stiffness related to TGF- $\beta$ pathway activation may also reinstate cell proliferation [149]. TGF- $\beta$, which controls the expression of the inhibitor of differentiation family of proteins (ID), has been reported to promote metastasis and regulate the dormant state of cancer cells. In this line, increased ID1 and ID3 expression in basal or triple-negative breast tumors reactivates and sustains cancer cell proliferation in the lung during metastatic colonization [150,151]. On the other hand, Coco, a secreted antagonist of TGF- $\beta$ ligands, has been reported to facilitate escape of dormancy in disseminated breast cancer cells by blocking BMP signaling, thus inducing lung-specific colonization [152]. Additionally, disseminated prostate cancer cells in the bone marrow have been shown to escape their dormant state by downregulating TGF- $\beta 2$ expression and activating its downstream target myosin light chain kinase (MLCK) [153].

Eventually, environmental pressure will select for metastatic cells able to escape the cytotoxic activity of TILs, a process denominated as "immunoediting" [138,139,154,155]. As reviewed in the 2011 update of the hallmarks of cancer, cancer cells co-opt inflammatory cells to assist their expansion, while evading antitumor activity of TILs [156]. However, how nascent metastases evade antitumor immunity still needs to be fully addressed. Here we revisit four global strategies that metastatic initiating cells may adopt to escape antitumor immunity and grow into full-blown metastases.

First, dormant cells as well as slow-cycling cancer cells may evade direct recognition from TILs ab initio. DTCs are stochastically primed to grow into full-blown metastasis, which is prevented by NK-mediated immunosurveillance. Indeed, when NK cells are depleted using NK-specific monoclonal antibodies, the amount of lung metastases increases in a mouse model of latent metastatic breast cancer [120]. Consequently, SOX9-expressing dormant cancer cells impair NK cytotoxic activity by downregulating ULBP activators of NKG2D receptors on NK cells [120,157]. In a clinical study, downregulation of ULBP1 was detected in CTCs and might be a result of EMT [158]. Alternatively, CD8+ T cell recognition could be avoided by masking antigenic presentation. In a study using $\mathrm{T}$ cells engineered to detect and kill GFP-expressing cells (JEDI cells), Agudo and colleagues showed that quiescent Lgr5-GFP+ adult skin stem cells may evade T cell recognition by downregulating expression of MHC-I, a mechanism that could also apply to quiescent/dormant cancer cells [159].

A second mechanism involves the generation of a permissive, anti-inflammatory PMN prior to organ colonization, with cells exerting immunosuppressive roles such as macrophages, myeloid-derived suppressor cells (MDSCs), and neutrophils $[85,98,160]$. Supporting this possibility, a recent study evidenced that immune evasion may already occur in lung premalignant lesions [161], where circulating IL-6 induced macrophage polarization into an immunosuppressive state and decreased TIL infiltration through the STAT3 pathway [162]. In this context, CAFs may participate to suppressing antitumor immunity by different means, including secretion anti-inflammatory cytokines [89,99,163-165], modulation of ECM stiffness [166-168] and direct inhibition of CD8+ TILs through MHC-II antigen presentation [169,170]. Of note, CAFs are the main producer of IL- 6 in primary tumors and may be a potential source of circulating IL-6 programming distant immunosuppressive PMN [97,163,171,172].

As a third mechanism, the activation of certain oncogenes in DTCs could trigger the secretion of anti-inflammatory cytokines, which dampens antitumor immunity. This process has been termed as the "intrinsic pathway" of cancer immunity $[173,174]$. In this context, TGF- $\beta$ is probably the most prominent anti-inflammatory cytokine, which exerts a plethora of immunosuppressive effects on the tumor immune microenvironment [175]. 
For instance, TGF- $\beta$ may be secreted by metastatic initiating cells in order to modulate T cell exclusion in CRC, consequently allowing efficient metastatic initiation by avoiding TIL immunosurveillance $[86,88,176]$. Furthermore, TGF- $\beta$ mediates expansion of regulatory T cells (Treg), which in turn impairs antitumoral response [175].

A final mechanism may imply the expression of immune checkpoint ligands by DTCs, for example, PD-L1, the ligand of the programmed death receptor 1 (PD-1). The PD-1/PDL1 pathway is one of the most well-understood inhibitory mechanisms of adaptive immunity. While PD-1 is expressed almost exclusively by lymphocytes, PD-L1 expression can be triggered by TIL-secreted IFN $\gamma$ in multiple cell subtypes of the tumor microenvironment, including the cancer cells [177-181]. Primary tumors with high PD-L1 expression are likely to generate PD-L1+ distant metastases [145], which implies that CTCs may already present surface expression of PD-L1 and resistance to TIL-mediated immune surveillance [182-187]. Indeed, expression of PD-L1 in EMT-like CTCs predicts reduced survival in patients with non-small cell lung cancer [188]. Metastatic initiating cells can also co-opt CTLA-4 immune checkpoint to avoid T cell activation-for instance, TGF- $\beta$-induced CSC expression of CD80, leading to $\mathrm{T}$ cell inhibition through the CD80-CTLA-4 axis in pre-clinical models of squamous cell carcinoma [189].

\section{Clinical Perspectives}

Cancer therapy has experienced significant improvements during recent decades. However, advanced cancer, especially metastatic disease, remains extremely difficult to cure. As discussed above, CTCs or dormant DTCs persist often undetected as MRD after treatment and represent a threat of relapse and metastasis formation. Furthermore, the number of resistant CTCs increases after therapy [9,33]. Therefore, early detection of MRD has become a priority for monitoring cancer progression and preventive therapy.

Currently, MRD can be assessed by detecting CTCs and/or circulating tumor DNA (ctDNA) in peripheral blood by performing liquid biopsies (LB), which are far less invasive than biopsies from solid tumors. Hence, new techniques are being established to accurately detect CTCs and CTC clusters in plasma [187,190-192]. A better understanding of CTCs could lead to more accurate monitoring of tumor responses and patient stratification [13,193]. In this regard, modelling metastatic dissemination using patient-derived xenograft (PDX) mouse models can elucidate the heterogeneity of CTCs and their possible outcomes in patients $[12,194]$. Indeed, detection of CTC clusters and stem-like CTCs is correlated with decreased disease-free survival [13,33,185,195]. Alternatively, ctDNA released by apoptotic cancer cells including CTCs and DTCs can be detected thanks to their specific cancer-associated mutation pattern. In recent clinical studies, almost all patients with MRD from CRC had detectable levels of ctDNA in the blood stream. In this context, presence of ctDNA was correlated with a worse outcome [196,197]. Early detection of MRD by following CTCs and ctDNA in LB will provide valuable tools for decision-making and clinical management of cancer patients.

Immunotherapy based on blocking antibodies against immune checkpoint receptors and ligands, including PD-1/PD-L1, CTLA-4 and NKG2A, is of particular interest in the clinical setting [187,198-203]. Immune checkpoint inhibitors (ICI) have proven effective in "immunologically hot tumors", such as melanoma and lung cancer [204], which are densely infiltrated with lymphocytes [205]. In opposition, treatment with ICI of immuneexcluded "immunologically cold tumors", which encompass most solid tumors, is still challenging. In this regard, the TGF- $\beta$ has arisen as a likely cause for the immune exclusion observed in cold tumors. In mouse models of colorectal and urothelial cancers, combination of TGF- $\beta$-pathway inhibitors with ICI leads to an amplification of antitumor immune responses, whereas ICI alone typically fail $[168,176,206]$. Additionally, recent clinical trials have shown that standard-of-care procedures such as radiotherapy, chemotherapy and oncogene-targeted therapies might raise antitumor immunity, thus leading to improved survival in patients when ICI are added [207-211]. As discussed above, immune evasion from NK and T cell surveillance characterizes all steps of efficient metastatic progression, from CTC release to the generation of overt metastases. Indeed, CTCs, DTCs and metastatic 
initiating cells take advantage of the expression of checkpoint ligands such as PD-L1 to escape TIL antitumor activity in a similar fashion to macrometastases. Thus, ICI-based anticancer strategy may be especially relevant against MRD.

The spectrum of responses to immunotherapy has underscored the relevance of immunologic biomarkers to predict benefit from therapy [205,212]. Perhaps one of the best examples is a phase II clinical trial designed to treat multiple solid tumors with Pembrolizumab, an anti-PD-1 antibody. This trial demonstrated that patients bearing tumors with microsatellite instability (MSI), which correlates with increased lymphocytes infiltration, were responding better to treatment when compared to patients with microsatellite stable (MSS) tumors [213]. With few exceptions, an increased density of TILs, particularly CD8+ cytotoxic T cells, is correlated with better responses to ICI and increased overall survival [214-218]. This trait could be exploited to create new diagnostic tools predicting patient response to treatment and guiding decision-making $[219,220]$. In this line, recent studies have shown that treatment with ICI enhances a peripheral T cell response correlated with increased TILs [221-225]. This finding opens the possibility of early patient stratification by detecting relevant immune populations in LB [224,226].

In conclusion, a better understanding of MRD will pave the way for a more accurate and personalized management of anticancer therapies. It is worth noting that several clinical trials are currently investigating the predictive power of ctDNA, CTCs, soluble factors and peripheral immune populations for cancer progression and response to therapy (see Table 1). Given its limited invasiveness, repeated LB enables dynamic monitoring of MRD and may potentially help to foresee metastatic initiation.

Table 1. Clinical trials currently exploring liquid biopsy as a source of novel biomarkers of cancer progression and treatment. CTCs = circulating tumor cells; ctDNA = circulating tumor DNA. Source: https: / clinicaltrials.gov.

\begin{tabular}{|c|c|c|c|c|}
\hline Identifier & Diagnostic Parameter & Disease & Objective & Starting Year \\
\hline NCT02072616 & \multirow{5}{*}{ CTCs } & $\begin{array}{l}\text { Pancreatic } \\
\text { adenocarcinoma }\end{array}$ & $\begin{array}{l}\text { Determination of the diagnostic accuracy } \\
\text { of the combined detection of CTCs and } \\
\text { circulating tumor DNA for the diagnosis } \\
\text { of pancreatic adenocarcinoma }\end{array}$ & 2014 \\
\hline NCT04239105 & & Breast neoplasms & $\begin{array}{l}\text { Establishment of the Raman Spectrum } \\
\text { Device for CTCs detection and to analyze } \\
\text { fluctuations of CTC numbers during } \\
\text { chemotherapy and neoadjuvant } \\
\text { chemotherapy. }\end{array}$ & 2020 \\
\hline NCT02827344 & & $\begin{array}{l}\text { Non-small cell lung } \\
\text { cancer }\end{array}$ & $\begin{array}{l}\text { Feasibility of the analysis of PD-L1 } \\
\text { expression on CTCs and evolution of the } \\
\text { percentage of PD-L1-expressing CTCs } \\
\text { prior and after receiving immunotherapy. }\end{array}$ & 2016 \\
\hline NCT03213041 & & Metastatic breast cancer & $\begin{array}{c}\text { Evaluation of the clinical impact of } \\
\text { treatment with pembrolizumab and } \\
\text { carboplatin by detecting and measuring } \\
\text { CTCs. }\end{array}$ & 2017 \\
\hline NCT02812680 & & Esophageal cancer & $\begin{array}{l}\text { Use of CTCs as predictive biomarkers for } \\
\text { neoadjuvant therapy using CTC chips. }\end{array}$ & 2016 \\
\hline NCT04367311 & \multirow{2}{*}{ ctDNA } & Lung cancer & $\begin{array}{l}\text { Assessment of ctDNA clearance to } \\
\text { determine responses to adjuvant } \\
\text { chemotherapy + Atezolizumab. }\end{array}$ & 2020 \\
\hline NCT04148066 & & $\begin{array}{l}\text { Non-small cell lung } \\
\text { cancer }\end{array}$ & $\begin{array}{l}\text { Prediction of patients with cancer cell } \\
\text { clones resistant to Osimertinib and } \\
\text { Crizotinib by ctDNA detection. }\end{array}$ & 2019 \\
\hline
\end{tabular}


Table 1. Cont.

\begin{tabular}{|c|c|c|c|c|}
\hline Identifier & Diagnostic Parameter & Disease & Objective & Starting Year \\
\hline NCT04353557 & & Breast cancer & $\begin{array}{l}\text { Post-operative kinetics and association } \\
\text { with time to recurrence of detected } \\
\text { ctDNA. }\end{array}$ & 2020 \\
\hline NCT03926260 & & $\begin{array}{l}\text { Metastatic non-small } \\
\text { cell lung cancer }\end{array}$ & $\begin{array}{l}\text { Identification of early patient response to } \\
\text { treatment by detecting changes in ctDNA } \\
\text { concentration. }\end{array}$ & 2019 \\
\hline NCT04259944 & & Colon cancer & $\begin{array}{c}\text { Use of fluctuations of ctDNA } \\
\text { concentration for patient allocation to } \\
\text { receive Capecitabine, CAPOX or FOLFIRI } \\
\text { after surgery. }\end{array}$ & 2020 \\
\hline NCT04135079 & \multirow{4}{*}{ Peripheral leukocytes } & Multiple myeloma & $\begin{array}{l}\text { Evaluation of immune transcriptome } \\
\text { profile from peripheral blood } \\
\text { mononuclear cells by RNAseq and } \\
\text { CyTOF and cytokine profiling. }\end{array}$ & 2019 \\
\hline NCT04127864 & & Colorectal cancer & $\begin{array}{l}\text { Determination of alterations of cytokine } \\
\text { profiles in blood from patients in response } \\
\text { to surgery. }\end{array}$ & 2019 \\
\hline NCT03493581 & & $\begin{array}{l}\text { Non-small cell lung } \\
\text { cancer }\end{array}$ & $\begin{array}{c}\text { Immune profiling of peripheral } \\
\text { monocytes, B, T, NK and dendritic cells to } \\
\text { assess resistance to anti-PD-1 } \\
\text { immunotherapy. }\end{array}$ & 2018 \\
\hline NCT04464122 & & $\begin{array}{l}\text { Neuroendocrine } \\
\text { tumors }\end{array}$ & $\begin{array}{l}\text { Immune profiling for diagnosis and } \\
\text { evaluation of response to chemotherapy } \\
\text { in locally advanced or metastatic cancer. }\end{array}$ & 2020 \\
\hline
\end{tabular}

Author Contributions: J.B.-R., J.L., A.G.-L. and A.C. contributed to manuscript preparation (writing, discussing and editing). All authors have read and agreed to the published version of the manuscript.

Funding: This work has been supported by grants to A.C. from Instituto de Salud Carlos III with FEDER/FSE co-financing (CP16/00151; PI17/00211), to J.L. from the Spanish Association against Cancer (AECC; Junior Clinician fellowship).

Institutional Review Board Statement: Not applicable.

Informed Consent Statement: Not applicable.

Data Availability Statement: All data presented in this review is freely available.

Conflicts of Interest: The authors declare no conflict of interest.

\section{References}

1. Nagrath, S.; Sequist, L.V.; Maheswaran, S.; Bell, D.W.; Irimia, D.; Ulkus, L.; Smith, M.R.; Kwak, E.L.; Digumarthy, S.; Muzikansky, A.; et al. Isolation of rare circulating tumour cells in cancer patients by microchip technology. Nature 2007, 450, 1235-1239. [CrossRef] [PubMed]

2. Massagué, J.; Obenauf, A.C. Metastatic colonization by circulating tumour cells. Nature 2016, 529, 298-306. [CrossRef] [PubMed]

3. Lambert, A.W.; Pattabiraman, D.R.; Weinberg, R.A. Emerging Biological Principles of Metastasis. Cell 2017, 168, 670-691. [CrossRef] [PubMed]

4. Yang, J.; Antin, P.; Berx, G.; Blanpain, C.; Brabletz, T.; Bronner, M.; Campbell, K.; Cano, A.; Casanova, J.; Christofori, G.; et al. Guidelines and definitions for research on epithelial-mesenchymal transition. Nat. Rev. Mol. Cell Biol. 2020, 21, 341-352. [CrossRef]

5. Dongre, A.; Weinberg, R.A. New insights into the mechanisms of epithelial-mesenchymal transition and implications for cancer. Nat. Rev. Mol. Cell Biol. 2019, 20, 69-84. [CrossRef]

6. Mani, S.A.; Guo, W.; Liao, M.J.; Eaton, E.N.; Ayyanan, A.; Zhou, A.Y.; Brooks, M.; Reinhard, F.; Zhang, C.C.; Shipitsin, M.; et al. The Epithelial-Mesenchymal Transition Generates Cells with Properties of Stem Cells. Cell 2008, 133, 704-715. [CrossRef]

7. Zhang, X.; Yin, X.; Zhang, H.; Sun, G.; Yang, Y.; Chen, J.; Shu, K.; Zhao, J.; Zhao, P.; Chen, N.; et al. Differential expression of TIM-3 between primary and metastatic sites in renal cell carcinoma. BMC Cancer 2019, 19, 1-10. [CrossRef] 
8. Mego, M.; Karaba, M.; Minarik, G.; Benca, J.; Silvia, J.; Sedlackova, T.; Manasova, D.; Kalavska, K.; Pindak, D.; Cristofanilli, M.; et al. Circulating Tumor Cells with Epithelial-to-mesenchymal Transition Phenotypes Associated with Inferior Outcomes in Primary Breast Cancer. Anticancer Res. 2019, 39, 1829-1837. [CrossRef]

9. Papadaki, M.A.; Stoupis, G.; Theodoropoulos, P.A.; Mavroudis, D.; Georgoulias, V.; Agelaki, S. Circulating tumor cells with stemness and epithelial-to-mesenchymal transition features are chemoresistant and predictive of poor outcome in metastatic breast cancer. Mol. Cancer Ther. 2019, 18, 437-447. [CrossRef]

10. Genna, A.; Vanwynsberghe, A.M.; Villard, A.V.; Pottier, C.; Ancel, J.; Polette, M.; Gilles, C. Emt-associated heterogeneity in circulating tumor cells: Sticky friends on the road to metastasis. Cancers 2020, 12, 1632. [CrossRef]

11. Peng, H.; Tan, X.; Wang, Y.; Dai, L.; Liang, G.; Guo, J.; Chen, M. Clinical significance of Ki67 and circulating tumor cells with an epithelial-mesenchymal transition phenotype in non-small cell lung cancer. Am. J. Transl. Res. 2020, 12, 2916-2928. [PubMed]

12. Razmara, A.M.; Sollier, E.; Kisirkoi, G.N.; Baker, S.W.; Bellon, M.B.; McMillan, A.; Lemaire, C.A.; Ramani, V.C.; Jeffrey, S.S.; Casey, K.M. Tumor shedding and metastatic progression after tumor excision in patient-derived orthotopic xenograft models of triple-negative breast cancer. Clin. Exp. Metastasis 2020, 37, 413-424. [CrossRef] [PubMed]

13. Savelieva, O.E.; Tashireva, L.A.; Kaigorodova, E.V.; Buzenkova, A.V.; Mukhamedzhanov, R.K.; Grigoryeva, E.S.; Zavyalova, M.V.; Tarabanovskaya, N.A.; Cherdyntseva, N.V.; Perelmuter, V.M. Heterogeneity of stemlike circulating tumor cells in invasive breast cancer. Int. J. Mol. Sci. 2020, 21, 2780. [CrossRef] [PubMed]

14. Aceto, N.; Bardia, A.; Miyamoto, D.T.; Donaldson, M.C.; Wittner, B.S.; Spencer, J.A.; Yu, M.; Pely, A.; Engstrom, A.; Zhu, H.; et al. Circulating tumor cell clusters are oligoclonal precursors of breast cancer metastasis. Cell 2014, 158, 1110-1122. [CrossRef] [PubMed]

15. Gkountela, S.; Castro-Giner, F.; Szczerba, B.M.; Vetter, M.; Landin, J.; Scherrer, R.; Krol, I.; Scheidmann, M.C.; Beisel, C.; Stirnimann, C.U.; et al. Circulating Tumor Cell Clustering Shapes DNA Methylation to Enable Metastasis Seeding. Cell 2019, 176, 98-112.e14. [CrossRef]

16. Campbell, K.; Rossi, F.; Adams, J.; Pitsidianaki, I.; Barriga, F.M.; Garcia-Gerique, L.; Batlle, E.; Casanova, J.; Casali, A. Collective cell migration and metastases induced by an epithelial-to-mesenchymal transition in Drosophila intestinal tumors. Nat. Commun. 2019, 10, 1-10. [CrossRef]

17. Bronsert, P.; Enderle-Ammour, K.; Bader, M.; Timme, S.; Kuehs, M.; Csanadi, A.; Kayser, G.; Kohler, I.; Bausch, D.; Hoeppner, J.; et al. Cancer cell invasion and EMT marker expression: A three-dimensional study of the human cancer-host interface. J. Pathol. 2014, 234, 410-422. [CrossRef]

18. Jain, S.; Cachoux, V.M.L.; Narayana, G.H.N.S.; de Beco, S.; D’Alessandro, J.; Cellerin, V.; Chen, T.; Heuzé, M.L.; Marcq, P.; Mège, R.M.; et al. The role of single-cell mechanical behaviour and polarity in driving collective cell migration. Nat. Phys. 2020, 16, 802-809. [CrossRef]

19. Tripathi, S.; Jolly, M.K.; Woodward, W.A.; Levine, H.; Deem, M.W. Analysis of hierarchical organization in gene expression networks reveals underlying principles of collective tumor cell dissemination and metastatic aggressiveness of inflammatory breast cancer. Front. Oncol. 2018, 8, 1-14. [CrossRef]

20. Lo, H.C.; Xu, Z.; Kim, I.S.; Pingel, B.; Aguirre, S.; Kodali, S.; Liu, J.; Zhang, W.; Muscarella, A.M.; Hein, S.M.; et al. Resistance to natural killer cell immunosurveillance confers a selective advantage to polyclonal metastasis. Nat. Cancer 2020, 1, 709-722. [CrossRef]

21. Wrenn, E.D.; Yamamoto, A.; Moore, B.M.; Huang, Y.; McBirney, M.; Thomas, A.J.; Greenwood, E.; Rabena, Y.F.; Rahbar, H.; Partridge, S.C.; et al. Regulation of Collective Metastasis by Nanolumenal Signaling. Cell 2020, 183, 395-410.e19. [CrossRef] [PubMed]

22. Zhang, X.; Ruan, Q.; Zhai, Y.; Lu, D.; Li, C.; Fu, Y.; Zheng, Z.; Song, Y.; Guo, J. Baicalein inhibits non-small-cell lung cancer invasion and metastasis by reducing ezrin tension in inflammation microenvironment. Cancer Sci. 2020, 111, 3802-3812. [CrossRef] [PubMed]

23. Libanje, F.; Raingeaud, J.; Luan, R.; Thomas, Z.; Zajac, O.; Veiga, J.; Marisa, L.; Adam, J.; Boige, V.; Malka, D.; et al. ROCK 2 inhibition triggers the collective invasion of colorectal adenocarcinomas. EMBO J. 2019, 38, 1-23. [CrossRef] [PubMed]

24. VanderVorst, K.; Dreyer, C.A.; Konopelski, S.E.; Lee, H.; Ho, H.Y.H.; Carraway, K.L. Wnt/PCP signaling contribution to carcinoma collective cell migration and metastasis. Cancer Res. 2019, 79, 1719-1729. [CrossRef]

25. Wang, T.; Hamilla, S.; Cam, M.; Aranda-Espinoza, H.; Mili, S. Extracellular matrix stiffness and cell contractility control RNA localization to promote cell migration. Nat. Commun. 2017, 8. [CrossRef]

26. Chrisafis, G.; Wang, T.; Moissoglu, K.; Gasparski, A.N.; Ng, Y.; Weigert, R.; Lockett, S.J.; Mili, S. Collective cancer cell invasion requires RNA accumulation at the invasive front. Proc. Natl. Acad. Sci. USA 2020, 117, 27423-27434. [CrossRef]

27. De Assis Lima, M.; da Silva, S.V.; Serrano-Garrido, O.; Hülsemann, M.; dos Santos Neres, L.; Rodríguez-Manzaneque, J.C.; Hodgson, L.; Freitas, V.M. Metalloprotease ADAMTS-1 decreases cell migration and invasion modulating the spatiotemporal dynamics of Cdc42 activity. Cell. Signal. 2020, 109827. [CrossRef]

28. Moissoglu, K.; Stueland, M.; Gasparski, A.N.; Wang, T.; Jenkins, L.M.; Hastings, M.L.; Mili, S. RNA localization and cotranslational interactions control RAB 13 GTP ase function and cell migration. EMBO J. 2020, 39, 1-19. [CrossRef]

29. Karagiannis, G.S.; Schaeffer, D.F.; Cho, C.K.J.; Musrap, N.; Saraon, P.; Batruch, I.; Grin, A.; Mitrovic, B.; Kirsch, R.; Riddell, R.H.; et al. Collective migration of cancer-associated fibroblasts is enhanced by overexpression of tight junction-associated proteins claudin-11 and occludin. Mol. Oncol. 2014, 8, 178-195. [CrossRef]

30. Erdogan, B.; Ao, M.; White, L.M.; Means, A.L.; Brewer, B.M.; Yang, L.; Washington, M.K.; Shi, C.; Franco, O.E.; Weaver, A.M.; et al. Cancer-associated fibroblasts promote directional cancer cell migration by aligning fibronectin. J. Cell Biol. 2017, 216, 37993816. [CrossRef] 
31. Labernadie, A.; Kato, T.; Brugués, A.; Serra-Picamal, X.; Derzsi, S.; Arwert, E.; Weston, A.; González-Tarragó, V.; Elosegui-Artola, A.; Albertazzi, L.; et al. A mechanically active heterotypic E-cadherin/ $\mathrm{N}$-cadherin adhesion enables fibroblasts to drive cancer cell invasion. Nat. Cell Biol. 2017, 19, 224-237. [CrossRef] [PubMed]

32. Kasashima, H.; Duran, A.; Martinez-Ordoñez, A.; Nakanishi, Y.; Kinoshita, H.; Linares, J.F.; Reina-Campos, M.; Kudo, Y.; L'Hermitte, A.; Yashiro, M.; et al. Stromal SOX2 Upregulation Promotes Tumorigenesis through the Generation of a SFRP1/2Expressing Cancer-Associated Fibroblast Population. Dev. Cell 2020, 1-16. [CrossRef]

33. Ortiz-Otero, N.; Marshall, J.R.; Lash, B.; King, M.R. Chemotherapy-induced release of circulating-tumor cells into the bloodstream in collective migration units with cancer-associated fibroblasts in metastatic cancer patients. BMC Cancer 2020, 20, 1-13. [CrossRef] [PubMed]

34. Wu, H.J.; Hao, M.; Yeo, S.K.; Guan, J.L. FAK signaling in cancer-associated fibroblasts promotes breast cancer cell migration and metastasis by exosomal miRNAs-mediated intercellular communication. Oncogene 2020, 39, 2539-2549. [CrossRef]

35. Follain, G.; Herrmann, D.; Harlepp, S.; Hyenne, V.; Osmani, N.; Warren, S.C.; Timpson, P.; Goetz, J.G. Fluids and their mechanics in tumour transit: Shaping metastasis. Nat. Rev. Cancer 2020, 20, 107-124. [CrossRef]

36. Hamidi, H.; Ivaska, J. Every step of the way: Integrins in cancer progression and metastasis. Nat. Rev. Cancer 2018, 1-16. [CrossRef]

37. Heeke, S.; Mograbi, B.; Alix-Panabières, C.; Hofman, P. Never Travel Alone: The Crosstalk of Circulating Tumor Cells and the Blood Microenvironment. Cells 2019, 8, 714. [CrossRef]

38. In 't Veld, S.G.J.G.; Wurdinger, T. Tumor-educated platelets. Blood 2019, 133, 2359-2364. [CrossRef]

39. Deng, X.; Feng, Z.; Zhu, L.; Chen, N.; Deng, Y.; Li, Y.; Li, R.; Wang, L.; Luo, M.; Wu, J. Platelet-Derived Factor V Is an Important Determinant of the Metastatic Potential of Circulating Tumor Cells. Front. Oncol. 2020, 10, 558306. [CrossRef]

40. Kassassir, H.; Karolczak, K.; Siewiera, K.M.; Wojkowska, D.W.; Braun, M.; Watala, C.W. Time-dependent interactions of blood platelets and cancer cells, accompanied by extramedullary hematopoiesis, lead to increased platelet activation and reactivity in a mouse orthotopic model of breast cancer - implications for pulmonary and liver metastas. Aging (Albany. NY) 2020, 12, 5091-5120. [CrossRef]

41. Yu, L.X.; Yan, L.; Yang, W.; Wu, F.Q.; Ling, Y.; Chen, S.Z.; Tang, L.; Tan, Y.X.; Cao, D.; Wu, M.C.; et al. Platelets promote tumour metastasis via interaction between TLR4 and tumour cell-released high-mobility group box1 protein. Nat. Commun. 2014, 5. [CrossRef] [PubMed]

42. Szczerba, B.M.; Castro-Giner, F.; Vetter, M.; Krol, I.; Gkountela, S.; Landin, J.; Scheidmann, M.C.; Donato, C.; Scherrer, R.; Singer, J.; et al. Neutrophils escort circulating tumour cells to enable cell cycle progression. Nature 2019, 566, 553-557. [CrossRef] [PubMed]

43. Fares, J.; Fares, M.Y.; Khachfe, H.H.; Salhab, H.A.; Fares, Y. Molecular principles of metastasis: A hallmark of cancer revisited. Signal Transduct. Target. Ther. 2020, 5. [CrossRef] [PubMed]

44. López-Soto, A.; Huergo-Zapico, L.; Galván, J.A.; Rodrigo, L.; de Herreros, A.G.; Astudillo, A.; Gonzalez, S. EpithelialMesenchymal Transition Induces an Antitumor Immune Response Mediated by NKG2D Receptor. J. Immunol. 2013, 190, 4408-4419. [CrossRef] [PubMed]

45. Chockley, P.J.; Chen, J.; Chen, G.; Beer, D.G.; Standiford, T.J.; Keshamouni, V.G. Epithelial-mesenchymal transition leads to NK cell-mediated metastasis-specific immunosurveillance in lung cancer. J. Clin. Investig. 2018, 128, 1384-1396. [CrossRef] [PubMed]

46. Lucotti, S.; Muschel, R.J. Platelets and Metastasis: New Implications of an Old Interplay. Front. Oncol. 2020, 10. [CrossRef] [PubMed]

47. Carrascal, M.A.; Talina, C.; Borralho, P.; Gonçalo Mineiro, A.; Henriques, A.R.; Pen, C.; Martins, M.; Braga, S.; Sackstein, R.; Videira, P.A. Staining of E-selectin ligands on paraffin-embedded sections of tumor tissue. BMC Cancer 2018, 18, 1-10. [CrossRef]

48. Li, S.S.; Ip, C.K.M.; Tang, M.Y.H.; Tang, M.K.S.; Tong, Y.; Zhang, J.; Hassan, A.A.; Mak, A.S.C.; Yung, S.; Chan, T.M.; et al. Sialyl Lewisx-P-selectin cascade mediates tumor-mesothelial adhesion in ascitic fluid shear flow. Nat. Commun. 2019, 10. [CrossRef]

49. Kim, K.J.; Kwon, S.H.; Yun, J.H.; Jeong, H.S.; Kim, H.R.; Lee, E.H.; Ye, S.K.; Cho, C.H. STAT3 activation in endothelial cells is important for tumor metastasis via increased cell adhesion molecule expression. Oncogene 2017, 36, 5445-5459. [CrossRef]

50. Miles, F.L.; Pruitt, F.L.; Van Golen, K.L.; Cooper, C.R. Stepping out of the flow: Capillary extravasation in cancer metastasis. Clin. Exp. Metastasis 2008, 25, 305-324. [CrossRef]

51. Reymond, N.; D'Água, B.B.; Ridley, A.J. Crossing the endothelial barrier during metastasis. Nat. Rev. Cancer 2013, 13, 858-870. [CrossRef] [PubMed]

52. Askari, J.A.; Buckley, P.A.; Mould, A.P.; Humphries, M.J. Linking integrin conformation to function. J. Cell Sci. 2009, 122, 165-170. [CrossRef] [PubMed]

53. Chen, M.B.; Lamar, J.M.; Li, R.; Hynes, R.O.; Kamm, R.D. Elucidation of the roles of tumor integrin $\beta 1$ in the extravasation stage of the metastasis cascade. Cancer Res. 2016, 76, 2513-2524. [CrossRef] [PubMed]

54. Stoletov, K.; Kato, H.; Zardouzian, E.; Kelber, J.; Yang, J.; Shattil, S.; Klemke, R. Visualizing extravasation dynamics of metastatic tumor cells. J. Cell Sci. 2010, 123, 2332-2341. [CrossRef] [PubMed]

55. Aragon-Sanabria, V.; Pohler, S.E.; Eswar, V.J.; Bierowski, M.; Gomez, E.W.; Dong, C. VE-Cadherin Disassembly and Cell Contractility in the Endothelium are Necessary for Barrier Disruption Induced by Tumor Cells. Sci. Rep. 2017, 7, 1-15. [CrossRef] [PubMed]

56. Tichet, M.; Prodhomme, V.; Fenouille, N.; Ambrosetti, D.; Mallavialle, A.; Cerezo, M.; Ohanna, M.; Audebert, S.; Rocchi, S.; Giacchero, D.; et al. Tumour-derived SPARC drives vascular permeability and extravasation through endothelial VCAM1 signalling to promote metastasis. Nat. Commun. 2015, 6. [CrossRef]

57. Hiratsuka, S.; Goel, S.; Kamoun, W.S.; Maru, Y.; Fukumura, D.; Duda, D.G.; Jain, R.K. Endothelial focal adhesion kinase mediates cancer cell homing to discrete regions of the lungs via E-selectin up-regulation. Proc. Natl. Acad. Sci. USA 2011, 108, 3725-3730. [CrossRef] 
58. Jiang, X.; Wong, K.H.K.; Khankhel, A.H.; Zeinali, M.; Reategui, E.; Phillips, M.J.; Luo, X.; Aceto, N.; Fachin, F.; Hoang, A.N.; et al. Microfluidic isolation of platelet-covered circulating tumor cells. Lab Chip 2017, 17, 3498-3503. [CrossRef]

59. Cloutier, N.; Paré, A.; Farndale, R.W.; Schumacher, H.R.; Nigrovic, P.A.; Lacroix, S.; Boilard, E. Platelets can enhance vascular permeability. Blood 2012, 120, 1334-1343. [CrossRef]

60. Marcolino, E.; Siddiqui, Y.H.; van den Bosch, M.; Poole, A.W.; Jayaraman, P.S.; Gaston, K. Blood platelets stimulate cancer extravasation through TGF $\beta$-mediated downregulation of PRH/HHEX. Oncogenesis 2020, 9. [CrossRef]

61. Takemoto, A.; Okitaka, M.; Takagi, S.; Takami, M.; Sato, S.; Nishio, M.; Okumura, S.; Fujita, N. A critical role of platelet TGF- $\beta$ release in podoplanin-mediated tumour invasion and metastasis. Sci. Rep. 2017, 7, 1-12. [CrossRef] [PubMed]

62. McDonald, B.; Spicer, J.; Giannais, B.; Fallavollita, L.; Brodt, P.; Ferri, L.E. Systemic inflammation increases cancer cell adhesion to hepatic sinusoids by neutrophil mediated mechanisms. Int. J. Cancer 2009, 125, 1298-1305. [CrossRef] [PubMed]

63. Strell, C.; Lang, K.; Niggemann, B.; Zaenker, K.S.; Entschladen, F. Surface molecules regulating rolling and adhesion to endothelium of neutrophil granulocytes and MDA-MB-468 breast carcinoma cells and their interaction. Cell. Mol. Life Sci. 2007, 64, 3306-3316. [CrossRef] [PubMed]

64. Wu, Q.D.I.; Wang, J.H.; Condron, C.; Bouchier-Hayes, D.; Paul Redmond, H. Human neutrophils facilitate tumor cell transendothelial migration. Am. J. Physiol.-Cell Physiol. 2001, 280, 814-822. [CrossRef] [PubMed]

65. Qian, B.; Deng, Y.; Im, J.H.; Muschel, R.J.; Zou, Y.; Li, J.; Lang, R.A.; Pollard, J.W. A distinct macrophage population mediates metastatic breast cancer cell extravasation, establishment and growth. PLoS ONE 2009, 4. [CrossRef]

66. Eichbaum, C.; Meyer, A.S.; Wang, N.; Bischofs, E.; Steinborn, A.; Bruckner, T.; Brodt, P.; Sohn, C.; Eichbaum, M.H.R. Breast cancer cell-derived cytokines, macrophages and cell adhesion: Implications for metastasis. Anticancer Res. 2011, 31, $3219-3227$.

67. Auguste, P.; Fallavollita, L.; Wang, N.; Burnier, J.; Bikfalvi, A.; Brodt, P. The host inflammatory response promotes liver metastasis by increasing tumor cell arrest and extravasation. Am. J. Pathol. 2007, 170, 1781-1792. [CrossRef]

68. Gupta, G.P.; Massagué, J. Cancer Metastasis: Building a Framework. Cell 2006, 127, 679-695. [CrossRef]

69. Tauriello, D.V.F.; Calon, A.; Lonardo, E.; Batlle, E. Determinants of metastatic competency in colorectal cancer. Mol. Oncol. 2017, 11, 97-119. [CrossRef]

70. Ganesh, K.; Basnet, H.; Kaygusuz, Y.; Laughney, A.M.; He, L.; Sharma, R.; O’Rourke, K.P.; Reuter, V.P.; Huang, Y.-H.; Turkekul, M.; et al. L1CAM defines the regenerative origin of metastasis-initiating cells in colorectal cancer. Nat. Cancer 2020, 1, 28-45. [CrossRef]

71. Valiente, M.; Obenauf, A.C.; Jin, X.; Chen, Q.; Zhang, X.H.F.; Lee, D.J.; Chaft, J.E.; Kris, M.G.; Huse, J.T.; Brogi, E.; et al. Serpins promote cancer cell survival and vascular Co-option in brain metastasis. Cell 2014, 156, 1002-1016. [CrossRef]

72. Zhou, W.; Fong, M.Y.; Min, Y.; Somlo, G.; Liu, L.; Palomares, M.R.; Yu, Y.; Chow, A.; O'Connor, S.T.F.; Chin, A.R.; et al. Cancer-Secreted miR-105 destroys vascular endothelial barriers to promote metastasis. Cancer Cell 2014, 25, 501-515. [CrossRef]

73. Obenauf, A.C.; Massagué, J. Surviving at a Distance: Organ-Specific Metastasis. Trends Cancer 2015, 1, 76-91. [CrossRef]

74. Padua, D.; Zhang, X.H.F.; Wang, Q.; Nadal, C.; Gerald, W.L.; Gomis, R.R.; Massagué, J. TGF $\beta$ Primes Breast Tumors for Lung Metastasis Seeding through Angiopoietin-like 4. Cell 2008, 133, 66-77. [CrossRef]

75. Urosevic, J.; Garcia-Albéniz, X.; Planet, E.; Real, S.; Céspedes, M.V.; Guiu, M.; Fernandez, E.; Bellmunt, A.; Gawrzak, S.; Pavlovic, M.; et al. Colon cancer cells colonize the lung from established liver metastases through p38 MAPK signalling and PTHLH. Nat. Cell Biol. 2014, 16, 685-694. [CrossRef]

76. Merlos-Suárez, A.; Barriga, F.M.; Jung, P.; Iglesias, M.; Céspedes, M.V.; Rossell, D.; Sevillano, M.; Hernando-Momblona, X.; Da Silva-Diz, V.; Muñoz, P.; et al. The intestinal stem cell signature identifies colorectal cancer stem cells and predicts disease relapse. Cell Stem Cell 2011, 8, 511-524. [CrossRef]

77. Cortina, C.; Turon, G.; Stork, D.; Hernando-Momblona, X.; Sevillano, M.; Aguilera, M.; Tosi, S.; Merlos-Suárez, A.; Stephan-Otto Attolini, C.; Sancho, E.; et al. A genome editing approach to study cancer stem cells in human tumors. EMBO Mol. Med. 2017, 9, 869-879. [CrossRef]

78. De Sousa E Melo, F.; Kurtova, A.V.; Harnoss, J.M.; Kljavin, N.; Hoeck, J.D.; Hung, J.; Anderson, J.E.; Storm, E.E.; Modrusan, Z.; Koeppen, H.; et al. A distinct role for Lgr5 + stem cells in primary and metastatic colon cancer. Nature 2017, 543, 676-680. [CrossRef]

79. Shimokawa, M.; Ohta, Y.; Nishikori, S.; Matano, M.; Takano, A.; Fujii, M.; Date, S.; Sugimoto, S.; Kanai, T.; Sato, T. Visualization and targeting of LGR5 + human colon cancer stem cells. Nature 2017, 545, 187-192. [CrossRef]

80. Lawson, D.A.; Bhakta, N.R.; Kessenbrock, K.; Prummel, K.D.; Yu, Y.; Takai, K.; Zhou, A.; Eyob, H.; Balakrishnan, S.; Wang, C.Y.; et al. Single-cell analysis reveals a stem-cell program in human metastatic breast cancer cells. Nature 2015, 526, 131-135. [CrossRef]

81. Langley, R.R.; Fidler, I.J. The seed and soil hypothesis revisited-The role of tumor-stroma interactions in metastasis to different organs. Int. J. Cancer 2011, 128, 2527-2535. [CrossRef] [PubMed]

82. Peinado, H.; Zhang, H.; Matei, I.R.; Costa-Silva, B.; Hoshino, A.; Rodrigues, G.; Psaila, B.; Kaplan, R.N.; Bromberg, J.F.; Kang, Y.; et al. Pre-metastatic niches: Organ-specific homes for metastases. Nat. Rev. Cancer 2017, 17, 302-317. [CrossRef] [PubMed]

83. Doglioni, G.; Parik, S.; Fendt, S.M. Interactions in the (pre)metastatic niche support metastasis formation. Front. Oncol. 2019, 9 , 1-7. [CrossRef] [PubMed]

84. Guo, Y.; Ji, X.; Liu, J.; Fan, D.; Zhou, Q.; Chen, C.; Wang, W.; Wang, G.; Wang, H.; Yuan, W.; et al. Effects of exosomes on pre-metastatic niche formation in tumors. Mol. Cancer 2019, 18, 1-11. [CrossRef] [PubMed]

85. Wortzel, I.; Dror, S.; Kenific, C.M.; Lyden, D. Exosome-Mediated Metastasis: Communication from a Distance. Dev. Cell 2019, 49, 347-360. [CrossRef] [PubMed] 
86. Calon, A.; Espinet, E.; Palomo-Ponce, S.; Tauriello, D.V.F.; Iglesias, M.; Céspedes, M.V.; Sevillano, M.; Nadal, C.; Jung, P.; Zhang, X.H.F.; et al. Dependency of Colorectal Cancer on a TGF- $\beta$-Driven Program in Stromal Cells for Metastasis Initiation. Cancer Cell 2012, 22, 571-584. [CrossRef]

87. Calon, A.; Tauriello, D.V.F.; Batlle, E. TGF-beta in CAF-mediated tumor growth and metastasis. Semin. Cancer Biol. 2014, 25, 15-22. [CrossRef]

88. Calon, A.; Lonardo, E.; Berenguer-Llergo, A.; Espinet, E.; Hernando-Momblona, X.; Iglesias, M.; Sevillano, M.; Palomo-Ponce, S.; Tauriello, D.V.F.; Byrom, D.; et al. Stromal gene expression defines poor-prognosis subtypes in colorectal cancer. Nat. Genet. 2015, 47, 320-329. [CrossRef]

89. Kalluri, R. The biology and function of fibroblasts in cancer. Nat. Rev. Cancer 2016, 16, 582-598. [CrossRef]

90. Pein, M.; Insua-Rodríguez, J.; Hongu, T.; Riedel, A.; Meier, J.; Wiedmann, L.; Decker, K.; Essers, M.A.G.; Sinn, H.P.; Spaich, S.; et al. Metastasis-initiating cells induce and exploit a fibroblast niche to fuel malignant colonization of the lungs. Nat. Commun. 2020, 11, 1-18. [CrossRef]

91. LeBleu, V.S.; Kalluri, R. A peek into cancer-associated fibroblasts: Origins, functions and translational impact. DMM Dis. Model. Mech. 2018, 11, 1-9. [CrossRef] [PubMed]

92. Zhang, X.H.F.; Jin, X.; Malladi, S.; Zou, Y.; Wen, Y.H.; Brogi, E.; Smid, M.; Foekens, J.A.; Massagué, J. Selection of bone metastasis seeds by mesenchymal signals in the primary tumor stroma. Cell 2013, 154, 1060-1073. [CrossRef] [PubMed]

93. Ligorio, M.; Sil, S.; Malagon-Lopez, J.; Nieman, L.T.; Misale, S.; Di Pilato, M.; Ebright, R.Y.; Karabacak, M.N.; Kulkarni, A.S.; Liu, A.; et al. Stromal Microenvironment Shapes the Intratumoral Architecture of Pancreatic Cancer. Cell 2019, 178, 160-175.e27. [CrossRef] [PubMed]

94. Vermeulen, L.; De Sousa E Melo, F.; Van Der Heijden, M.; Cameron, K.; De Jong, J.H.; Borovski, T.; Tuynman, J.B.; Todaro, M.; Merz, C.; Rodermond, H.; et al. Wnt activity defines colon cancer stem cells and is regulated by the microenvironment. Nat. Cell Biol. 2010, 12, 468-476. [CrossRef] [PubMed]

95. Saijo, A.; Goto, H.; Nakano, M.; Mitsuhashi, A.; Aono, Y.; Hanibuchi, M.; Ogawa, H.; Uehara, H.; Kondo, K.; Nishioka, Y. Bone Marrow-Derived Fibrocytes Promote Stem Cell-Like Properties of Lung Cancer Cells; Elsevier B.V.: Amsterdam, The Netherlands, 2018; Volume 421, ISBN 8188633712.

96. Patel, A.K.; Vipparthi, K.; Thatikonda, V.; Arun, I.; Bhattacharjee, S.; Sharan, R.; Arun, P.; Singh, S. A subtype of cancer-associated fibroblasts with lower expression of alpha-smooth muscle actin suppresses stemness through BMP4 in oral carcinoma. Oncogenesis 2018, 7. [CrossRef] [PubMed]

97. Su, S.; Chen, J.; Yao, H.; Liu, J.; Yu, S.; Lao, L.; Wang, M.; Luo, M.; Xing, Y.; Chen, F.; et al. CD10+GPR77+ Cancer-Associated Fibroblasts Promote Cancer Formation and Chemoresistance by Sustaining Cancer Stemness. Cell 2018, 172, 841-856.e16. [CrossRef]

98. Wculek, S.K.; Malanchi, I. Neutrophils support lung colonization of metastasis-initiating breast cancer cells. Nature 2015, 528, 413-417. [CrossRef]

99. Allaoui, R.; Bergenfelz, C.; Mohlin, S.; Hagerling, C.; Salari, K.; Werb, Z.; Anderson, R.L.; Ethier, S.P.; Jirström, K.; Påhlman, S.; et al. Cancer-associated fibroblast-secreted CXCL16 attracts monocytes to promote stroma activation in triple-negative breast cancers. Nat. Commun. 2016, 7. [CrossRef]

100. Nielsen, S.R.; Quaranta, V.; Linford, A.; Emeagi, P.; Rainer, C.; Santos, A.; Ireland, L.; Sakai, T.; Sakai, K.; Kim, Y.S.; et al. Macrophagesecreted granulin supports pancreatic cancer metastasis by inducing liver fibrosis. Nat. Cell Biol. 2016, 18, 549-560. [CrossRef]

101. Yang, Y.; Andersson, P.; Hosaka, K.; Zhang, Y.; Cao, R.; Iwamoto, H.; Yang, X.; Nakamura, M.; Wang, J.; Zhuang, R.; et al. The PDGF-BB-SOX7 axis-modulated IL-33 in pericytes and stromal cells promotes metastasis through tumour-associated macrophages. Nat. Commun. 2016, 7. [CrossRef]

102. Linde, N.; Casanova-Acebes, M.; Sosa, M.S.; Mortha, A.; Rahman, A.; Farias, E.; Harper, K.; Tardio, E.; Reyes Torres, I.; Jones, J.; et al. Macrophages orchestrate breast cancer early dissemination and metastasis. Nat. Commun. 2018, 9, 1-14. [CrossRef]

103. Chen, L.; Zheng, H.; Yu, X.; Liu, L.; Li, H.; Zhu, H.; Zhang, Z.; Lei, P.; Shen, G. Tumor-Secreted GRP78 Promotes the Establishment of a Pre-metastatic Niche in the Liver Microenvironment. Front. Immunol. 2020, 11, 1-13. [CrossRef] [PubMed]

104. Richmond, A.; Yang, J.; Yan, C.; Vilgelm, A.E.; Chen, S.; Ayers, G.D.; Johnson, C.A. Targeted Deletion of CXCR2 in Myeloid Cells Alters the Tumor Immune Environment to Improve Antitumor Immunity. Cancer Immunol. Res. 2020. [CrossRef]

105. Wang, Z.; Yang, C.; Li, L.; Zhang, Z.; Pan, J.; Su, K.; Chen, W.; Li, J.; Qiu, F.; Huang, J. CD62Ldim Neutrophils Specifically Migrate to the Lung and Participate in the Formation of the Pre-Metastatic Niche of Breast Cancer. Front. Oncol. 2020, 10, 1-13. [CrossRef] [PubMed]

106. Hadfield, G. The dormant cancer cell. Br. Med. J. 1954, 2, 607-611. [CrossRef]

107. Klein, C.A. Framework models of tumor dormancy from patient-derived observations. Curr. Opin. Genet. Dev. 2011, 21, 42-49. [CrossRef] [PubMed]

108. Nguyen, D.X.; Bos, P.D.; Massagué, J. Metastasis: From dissemination to organ-specific colonization. Nat. Rev. Cancer 2009, 9 , 274-284. [CrossRef]

109. Aguirre-Ghiso, J.A. Models, mechanisms and clinical evidence for cancer dormancy. Nat. Rev. Cancer 2007, 7, 834-846. [CrossRef]

110. Panigrahy, D.; Edin, M.L.; Lee, C.R.; Huang, S.; Bielenberg, D.R.; Butterfield, C.E.; Barnés, C.M.; Mammoto, A.; Mammoto, T.; Luria, A.; et al. Epoxyeicosanoids stimulate multiorgan metastasis and tumor dormancy escape in mice. J. Clin. Investig. 2012, 122, 178-191. [CrossRef] 
111. Indraccolo, S.; Minuzzo, S.; Masiero, M.; Pusceddu, I.; Persano, L.; Moserle, L.; Reboldi, A.; Favaro, E.; Mecarozzi, M.; Di Mario, G.; et al. Cross-talk between tumor and endothelial cells involving the Notch3-DII4 interaction marks escape from tumor dormancy. Cancer Res. 2009, 69, 1314-1323. [CrossRef]

112. Ghajar, C.M.; Peinado, H.; Mori, H.; Matei, I.R.; Evason, K.J.; Brazier, H.; Almeida, D.; Koller, A.; Hajjar, K.A.; Stainier, D.Y.R.; et al. The perivascular niche regulates breast tumour dormancy. Nat. Cell Biol. 2013, 15, 807-817. [CrossRef]

113. Almog, N.; Henke, V.; Flores, L.; Hlatky, L.; Kung, A.L.; Wright, R.D.; Berger, R.; Hutchinson, L.; Naumov, G.N.; Bender, E.; et al. Prolonged dormancy of human liposarcoma is associated with impaired tumor angiogenesis. FASEB J. 2006, 20, 947-949. [CrossRef]

114. Magnus, N.; Garnier, D.; Meehan, B.; McGraw, S.; Lee, T.H.; Caron, M.; Bourque, G.; Milsom, C.; Jabado, N.; Trasler, J.; et al. Tissue factor expression provokes escape from tumor dormancy and leads to genomic alterations. Proc. Natl. Acad. Sci. USA 2014, 111, 3544-3549. [CrossRef]

115. Johnson, R.W.; Finger, E.C.; Olcina, M.M.; Vilalta, M.; Aguilera, T.; Miao, Y.; Merkel, A.R.; Johnson, J.R.; Sterling, J.A.; Wu, J.Y.; et al. Induction of LIFR confers a dormancy phenotype in breast cancer cells disseminated to the bone marrow. Nat. Cell Biol. 2016, 18, 1078-1089. [CrossRef]

116. Shimizu, H.; Takeishi, S.; Nakatsumi, H.; Nakayama, K.I. Prevention of cancer dormancy by Fbxw7 ablation eradicates disseminated tumor cells. JCI Insight 2019, 4. [CrossRef]

117. Schewe, D.M.; Aguirre-Ghiso, J.A. ATF6 $\alpha$-Rheb-mTOR signaling promotes survival of dormant tumor cells in vivo. Proc. Natl. Acad. Sci. USA 2008, 105, 10519-10524. [CrossRef]

118. Balz, L.M.; Bartkowiak, K.; Andreas, A.; Pantel, K.; Niggemann, B.; Zänker, K.S.; Brandt, B.H.; Dittmar, T. The interplay of HER2/HER3/PI3K and EGFR/HER2/PLC- $\gamma 1$ signalling in breast cancer cell migration and dissemination. J. Pathol. 2012, 227, 234-244. [CrossRef]

119. Vera-Ramirez, L.; Vodnala, S.K.; Nini, R.; Hunter, K.W.; Green, J.E. Autophagy promotes the survival of dormant breast cancer cells and metastatic tumour recurrence. Nat. Commun. 2018, 9, 1-12. [CrossRef]

120. Malladi, S.; MacAlinao, D.G.; Jin, X.; He, L.; Basnet, H.; Zou, Y.; De Stanchina, E.; Massagué, J. Metastatic Latency and Immune Evasion through Autocrine Inhibition of WNT. Cell 2016, 165, 45-60. [CrossRef]

121. Bragado, P.; Sosa, M.S.; Keely, P.; Condeelis, J.; Aguirre-Ghiso, J.A. Microenvironments dictating tumor cell dormancy. Recent Results Cancer Res. 2012, 195, 25-39. [CrossRef]

122. Aguirre-Ghiso, J.A.; Bragado, P.; Sosa, M.S. Metastasis awakening: Targeting dormant cancer. Nat. Med. 2013, 19, $276-277$. [CrossRef] [PubMed]

123. Bragado, P.; Estrada, Y.; Parikh, F.; Krause, S.; Capobianco, C.; Farina, H.G.; Schewe, D.M.; Aguirre-Ghiso, J.A. TGF- $\beta 2$ dictates disseminated tumour cell fate in target organs through TGF- $\beta$-RIII and p38 $\alpha / \beta$ signalling. Nat. Cell Biol. 2013, 15, 1351-1361. [CrossRef] [PubMed]

124. Aguirre-Ghiso, J.A.; Estrada, Y.; Liu, D.; Ossowski, L. ERKMAPK activity as a determinant of tumor growth and dormancy; regulation by p38SAPK. Cancer Res. 2003, 63, 1684-1695. [CrossRef] [PubMed]

125. Vander Griend, D.J.; Kocherginsky, M.; Hickson, J.A.; Stadler, W.M.; Lin, A.; Rinker-Schaeffer, C.W. Suppression of metastatic colonization by the context-dependent activation of the c-Jun NH2-terminal kinase kinases JNKK1/MKK4 and MKK7. Cancer Res. 2005, 65, 10984-10991. [CrossRef] [PubMed]

126. Hickson, J.A.; Huo, D.; Vander Griend, D.J.; Lin, A.; Rinker-Schaeffer, C.W.; Yamada, S.D. The p38 kinases MKK4 and MKK6 suppress metastatic colonization in human ovarian carcinoma. Cancer Res. 2006, 66, 2264-2270. [CrossRef] [PubMed]

127. Deng, X.; Ewton, D.Z.; Friedman, E. Mirk dyrk1B maintains the viability of quiescent pancreatic cancer cells by reducing levels of reactive oxygen species. Cancer Res. 2009, 69, 3317-3324. [CrossRef]

128. Jin, K.; Ewton, D.Z.; Park, S.; Hu, J.; Friedman, E. Mirk regulates the exit of colon cancer cells from quiescence. J. Biol. Chem. 2009, 284, 22916-22925. [CrossRef]

129. Ewton, D.Z.; Hu, J.; Vilenchik, M.; Deng, X.; Luk, K.C.; Polonskaia, A.; Hoffman, A.F.; Zipf, K.; Boylan, J.F.; Friedman, E.A. Inactivation of Mirk/Dyrk1b kinase targets quiescent pancreatic cancer cells. Mol. Cancer Ther. 2011, 10, 2104-2114. [CrossRef]

130. Litovchick, L.; Florens, L.A.; Swanson, S.K.; Washburn, M.P.; Decaprio, J.A. DYRK1A protein kinase promotes quiescence and senescence through DREAM complex assembly. Genes Dev. 2011, 25, 801-813. [CrossRef]

131. Nobutani, K.; Shimono, Y.; Mizutani, K.; Ueda, Y.; Suzuki, T.; Kitayama, M.; Minami, A.; Momose, K.; Miyawaki, K.; Akashi, K.; et al. Downregulation of CXCR4 in metastasized breast cancer cells and implication in their dormancy. PLoS ONE 2015, 10, 1-17. [CrossRef]

132. El-Shennawy, L.; Dubrovskyi, O.; Kastrati, I.; Danes, J.M.; Zhang, Y.; Whiteley, H.E.; Creighton, C.J.; Frasor, J. Coactivation of estrogen receptor and IKKb induces a dormant metastatic phenotype in ER-Positive breast cancer. Cancer Res. 2018, 78, 974-984. [CrossRef]

133. Jiang, J.; Zheng, M.; Zhang, M.; Yang, X.; Li, L.; Wang, S.S.; Wu, J.S.; Yu, X.H.; Wu, J.B.; Pang, X.; et al. PRRX1 Regulates Cellular Phenotype Plasticity and Dormancy of Head and Neck Squamous Cell Carcinoma Through miR-642b-3p. Neoplasia 2019, 21, 216-229. [CrossRef]

134. Nash, K.T.; Phadke, P.A.; Navenot, J.M.; Hurst, D.R.; Accavitti-Loper, M.A.; Sztul, E.; Vaidya, K.S.; Frost, A.R.; Kappes, J.C.; Peiper, S.C.; et al. Requirement of KISS1 secretion for multiple organ metastasis suppression and maintenance of tumor dormancy. $J$. Natl. Cancer Inst. 2007, 99, 309-321. [CrossRef] 
135. Jiang, Y.; Berk, M.; Singh, L.S.; Tan, H.; Yin, L.; Powell, C.T.; Xu, Y. KiSS1 suppresses metastasis in human ovarian cancer via inhibition of protein kinase C alpha. Clin. Exp. Metastasis 2005, 22, 369-376. [CrossRef]

136. Ghiso, J.A.A.; Kovalski, K.; Ossowski, L. Human Carcinoma Involves Integrin and MAPK Signaling. October 1999, 147, 89-103.

137. Aguirre-Ghiso, J.A.; Liu, D.; Mignatti, A.; Kovalski, K.; Ossowski, L. Urokinase receptor and fibronectin regulate the ERKMAPK to p38MAPK activity ratios that determine carcinoma cell proliferation or dormancy in vivo. Mol. Biol. Cell 2001, 12, 863-879. [CrossRef]

138. O'Donnell, J.S.; Teng, M.W.L.; Smyth, M.J. Cancer immunoediting and resistance to T cell-based immunotherapy. Nat. Rev. Clin. Oncol. 2019, 16, 151-167. [CrossRef]

139. Dunn, G.P.; Koebel, C.M.; Schreiber, R.D. Interferons, immunity and cancer immunoediting. Nat. Rev. Immunol. 2006, 6, 836-848. [CrossRef]

140. Eyles, J.; Puaux, A.L.; Wang, X.; Toh, B.; Prakash, C.; Hong, M.; Tan, T.G.; Zheng, L.; Ong, L.C.; Jin, Y.; et al. Tumor cells disseminate early, but immunosurveillance limits metastatic outgrowth, in a mouse model of melanoma. J. Clin. Investig. 2010, 120, 2030-2039. [CrossRef]

141. Katlinski, K.V.; Gui, J.; Katlinskaya, Y.V.; Ortiz, A.; Bhattacharya, S.; Carbone, C.J.; Beiting, D.P.; Girondo, M.A.; Peck, A.R.; Puré, E.; et al. Inactivation of interferon receptor promotes the establishment of immune privileged tumor microenvironment. Cancer Cell 2017, 31, 194-207. [CrossRef]

142. Müller, M.; Gounari, F.; Prifti, S.; Hacker, H.J.; Schirrmacher, V.; Khazaie, K. EblacZ tumor dormancy in bone marrow and lymph nodes: Active control of proliferating tumor cells by CD8+ immune T cells. Cancer Res. 1998, 58, 5439-5446.

143. Feuerer, M.; Rocha, M.; Bai, L.; Umansky, V.; Solomayer, E.F.; Bastert, G.; Diel, I.J.; Schirrmacher, V. Enrichment of memory T cells and other profound immunological changes in the bone marrow from untreated breast cancer patients. Int. J. Cancer 2001, 92, 96-105. [CrossRef]

144. Bidwell, B.N.; Slaney, C.Y.; Withana, N.P.; Forster, S.; Cao, Y.; Loi, S.; Andrews, D.; Mikeska, T.; Mangan, N.E.; Samarajiwa, S.A.; et al. Silencing of Irf7 pathways in breast cancer cells promotes bone metastasis through immune escape. Nat. Med. 2012, 18, 1224-1231. [CrossRef] [PubMed]

145. Udager, A.M.; Liu, T.Y.; Skala, S.L.; Magers, M.J.; McDaniel, A.S.; Spratt, D.E.; Feng, F.Y.; Siddiqui, J.; Cao, X.; Fields, K.L.; et al. Frequent PD-L1 expression in primary and metastatic penile squamous cell carcinoma: Potential opportunities for immunotherapeutic approaches. Ann. Oncol. 2016, 27, 1706-1712. [CrossRef]

146. Cornel, A.M.; Mimpen, I.L.; Nierkens, S. MHC class I downregulation in cancer: Underlying mechanisms and potential targets for cancer immunotherapy. Cancers 2020, 12, 1760. [CrossRef]

147. Khazali, A.S.; Clark, A.M.; Wells, A. Inflammatory cytokine IL-8/CXCL8 promotes tumour escape from hepatocyte-induced dormancy. Br. J. Cancer 2018, 118, 566-576. [CrossRef]

148. Lu, X.; Mu, E.; Wei, Y.; Riethdorf, S.; Yang, Q.; Yuan, M.; Yan, J.; Hua, Y.; Tiede, B.J.; Lu, X.; et al. VCAM-1 Promotes Osteolytic Expansion of Indolent Bone Micrometastasis of Breast Cancer by Engaging $\alpha 4 \beta 1$-Positive Osteoclast Progenitors. Cancer Cell 2011, 20, 701-714. [CrossRef]

149. Barkan, D.; Green, J.E.; Chambers, A.F. Extracellular matrix: A gatekeeper in the transition from dormancy to metastatic growth. Eur. J. Cancer 2010, 46, 1181-1188. [CrossRef]

150. Gupta, G.P.; Perk, J.; Acharyya, S.; De Candia, P.; Mittal, V.; Todorova-Manova, K.; Gerald, W.L.; Brogi, E.; Benezra, R.; Massagué, J. ID genes mediate tumor reinitiation during breast cancer lung metastasis. Proc. Natl. Acad. Sci. USA 2007, 104, 19506-19511. [CrossRef]

151. Swarbrick, A.; Roy, E.; Allen, T.; Bishop, J.M. Id1 cooperates with oncogenic Ras to induce metastatic mammary carcinoma by subversion of the cellular senescence response. Proc. Natl. Acad. Sci. USA 2008, 105, 5402-5407. [CrossRef]

152. Gao, H.; Chakraborty, G.; Lee-Lim, A.P.; Mo, Q.; Decker, M.; Vonica, A.; Shen, R.; Brogi, E.; Brivanlou, A.H.; Giancotti, F.G. The BMP inhibitor Coco reactivates breast cancer cells at lung metastatic sites. Cell 2012, 150, 764-779. [CrossRef] [PubMed]

153. Ruppender, N.; Larson, S.; Lakely, B.; Kollath, L.; Brown, L.; Coleman, I.; Coleman, R.; Nguyen, H.; Nelson, P.S.; Corey, E.; et al. Cellular adhesion promotes prostate cancer cells escape from dormancy. PLoS ONE 2015, 10, 1-16. [CrossRef]

154. Dunn, G.P.; Bruce, A.T.; Ikeda, H.; Old, L.J.; Schreiber, R.D. Cancer immunoediting: From immunosurveillance to tumor escape. Nat. Immunol. 2002, 3, 991-998. [CrossRef] [PubMed]

155. Angelova, M.; Mlecnik, B.; Vasaturo, A.; Bindea, G.; Fredriksen, T.; Lafontaine, L.; Buttard, B.; Morgand, E.; Bruni, D.; JouretMourin, A.; et al. Evolution of Metastases in Space and Time under Immune Selection. Cell 2018, 175, 751-765.e16. [CrossRef]

156. Hanahan, D.; Weinberg, R.A. Hallmarks of cancer: The next generation. Cell 2011, 144, 646-674. [CrossRef] [PubMed]

157. Laughney, A.M.; Hu, J.; Campbell, N.R.; Bakhoum, S.F.; Setty, M.; Lavallée, V.P.; Xie, Y.; Masilionis, I.; Carr, A.J.; Kottapalli, S.; et al. Regenerative lineages and immune-mediated pruning in lung cancer metastasis. Nat. Med. 2020, 26, 259-269. [CrossRef] [PubMed]

158. Hu, B.; Tian, X.; Li, Y.; Liu, Y.; Yang, T.; Han, Z.; An, J.; Kong, L.; Li, Y. Epithelial-mesenchymal transition may be involved in the immune evasion of circulating gastric tumor cells via downregulation of ULBP1. Cancer Med. 2020, 9, 2686-2697. [CrossRef] [PubMed]

159. Agudo, J.; Park, E.S.; Rose, S.A.; Alibo, E.; Sweeney, R.; Dhainaut, M.; Kobayashi, K.S.; Sachidanandam, R.; Baccarini, A.; Merad, M.; et al. Quiescent Tissue Stem Cells Evade Immune Surveillance. Immunity 2018, 48, 271-285.e5. [CrossRef] 
160. Yan, H.H.; Pickup, M.; Pang, Y.; Gorska, A.E.; Li, Z.; Chytil, A.; Geng, Y.; Gray, J.W.; Moses, H.L.; Yang, L. Gr-1+CD11b+ myeloid cells tip the balance of immune protection to tumor promotion in the premetastatic lung. Cancer Res. 2010, 70, 6139-6149. [CrossRef]

161. Mascaux, C.; Angelova, M.; Vasaturo, A.; Beane, J.; Hijazi, K.; Anthoine, G.; Buttard, B.; Rothe, F.; Willard-Gallo, K.; Haller, A.; et al. Immune evasion before tumour invasion in early lung squamous carcinogenesis. Nature 2019, 571, 570-575. [CrossRef]

162. Jing, B.; Wang, T.; Sun, B.; Xu, J.; Xu, D.; Liao, Y.; Song, H.; Guo, W.; Li, K.; Hu, M.; et al. IL6/STAT3 signaling orchestrates premetastatic niche formation and immunosuppressive traits in lung. Cancer Res. 2020, 80, 784-797. [CrossRef] [PubMed]

163. Öhlund, D.; Handly-Santana, A.; Biffi, G.; Elyada, E.; Almeida, A.S.; Ponz-Sarvise, M.; Corbo, V.; Oni, T.E.; Hearn, S.A.; Lee, E.J.; et al. Distinct populations of inflammatory fibroblasts and myofibroblasts in pancreatic cancer. J. Exp. Med. 2017, 214, 579-596. [CrossRef] [PubMed]

164. Costa, A.; Kieffer, Y.; Scholer-Dahirel, A.; Pelon, F.; Bourachot, B.; Cardon, M.; Sirven, P.; Magagna, I.; Fuhrmann, L.; Bernard, C.; et al. Fibroblast Heterogeneity and Immunosuppressive Environment in Human Breast Cancer. Cancer Cell 2018, 33, 463-479.e10. [CrossRef] [PubMed]

165. Cremasco, V.; Astarita, J.L.; Grauel, A.L.; Keerthivasan, S.; MacIsaac, K.; Woodruff, M.C.; Wu, M.; Spel, L.; Santoro, S.; Amoozgar, Z.; et al. FAP delineates heterogeneous and functionally divergent stromal cells in immune-excluded breast tumors. Cancer Immunol. Res. 2018, 6, 1472-1485. [CrossRef] [PubMed]

166. Salmon, H.; Franciszkiewicz, K.; Damotte, D.; Dieu-Nosjean, M.C.; Validire, P.; Trautmann, A.; Mami-Chouaib, F.; Donnadieu, E. Matrix architecture defines the preferential localization and migration of T cells into the stroma of human lung tumors. J. Clin. Investig. 2012, 122, 899-910. [CrossRef] [PubMed]

167. Salmon, H.; Remark, R.; Gnjatic, S.; Merad, M. Host tissue determinants of tumour immunity. Nat. Rev. Cancer 2019, 19, 215-227. [CrossRef]

168. Chakravarthy, A.; Khan, L.; Bensler, N.P.; Bose, P.; De Carvalho, D.D. TGF- $\beta$-associated extracellular matrix genes link cancerassociated fibroblasts to immune evasion and immunotherapy failure. Nat. Commun. 2018, 9, 1-10. [CrossRef]

169. Lakins, M.A.; Ghorani, E.; Munir, H.; Martins, C.P.; Shields, J.D. Cancer-associated fibroblasts induce antigen-specific deletion of CD8 + T Cells to protect tumour cells. Nat. Commun. 2018, 9, 1-9. [CrossRef]

170. Elyada, E.; Bolisetty, M.; Laise, P.; Flynn, W.F.; Courtois, E.T.; Burkhart, R.A.; Teinor, J.A.; Belleau, P.; Biffi, G.; Lucito, M.S.; et al. Cross-species single-cell analysis of pancreatic ductal adenocarcinoma reveals antigen-presenting cancer-associated fibroblasts. Cancer Discov. 2019, 9, 1102-1123. [CrossRef]

171. Goulet, C.R.; Champagne, A.; Bernard, G.; Vandal, D.; Chabaud, S.; Pouliot, F.; Bolduc, S. Cancer-associated fibroblasts induce epithelial-mesenchymal transition of bladder cancer cells through paracrine IL-6 signalling. BMC Cancer 2019, 19, 1-13. [CrossRef]

172. Arwert, E.N.; Milford, E.L.; Rullan, A.; Derzsi, S.; Hooper, S.; Kato, T.; Mansfield, D.; Melcher, A.; Harrington, K.J.; Sahai, E. STING and IRF3 in stromal fibroblasts enable sensing of genomic stress in cancer cells to undermine oncolytic viral therapy. Nat. Cell Biol. 2020, 22, 758-766. [CrossRef] [PubMed]

173. Mantovani, A.; Allavena, P.; Sica, A.; Balkwill, F. Cancer-related inflammation. Nature 2008, 454, 436-444. [CrossRef]

174. Rasool, S.; Rutella, S.; Ferrone, S.; Maccalli, C. Cancer Stem Cells: The Players of Immune Evasion from Immunotherapy. In Cancer Stem Cell Resistance to Targeted Therapy; Springer: Cham, Germany, 2019; pp. 223-249.

175. Batlle, E.; Massagué, J. Transforming Growth Factor- $\beta$ Signaling in Immunity and Cancer. Immunity 2019, 50, 924-940. [CrossRef] [PubMed]

176. Tauriello, D.V.F.; Palomo-Ponce, S.; Stork, D.; Berenguer-Llergo, A.; Badia-Ramentol, J.; Iglesias, M.; Sevillano, M.; Ibiza, S.; Cañellas, A.; Hernando-Momblona, X.; et al. TGF $\beta$ drives immune evasion in genetically reconstituted colon cancer metastasis. Nature 2018, 554, 538-543. [CrossRef] [PubMed]

177. Bai, J.; Gao, Z.; Li, X.; Dong, L.; Han, W.; Nie, J. Regulation of PD-1/PD-L1 pathway and resistance to PD-1/PDL1 blockade. Oncotarget 2017, 8, 110693-110707. [CrossRef]

178. Garcia-Diaz, A.; Shin, D.S.; Moreno, B.H.; Saco, J.; Escuin-Ordinas, H.; Rodriguez, G.A.; Zaretsky, J.M.; Sun, L.; Hugo, W.; Wang, X.; et al. Interferon Receptor Signaling Pathways Regulating PD-L1 and PD-L2 Expression. Cell Rep. 2017, 19, 1189-1201. [CrossRef]

179. Ribas, A.; Dummer, R.; Puzanov, I.; VanderWalde, A.; Andtbacka, R.H.I.; Michielin, O.; Olszanski, A.J.; Malvehy, J.; Cebon, J.; Fernandez, E.; et al. Oncolytic Virotherapy Promotes Intratumoral T Cell Infiltration and Improves Anti-PD-1 Immunotherapy. Cell 2017, 170, 1109-1119.e10. [CrossRef]

180. Chen, S.; Crabill, G.A.; Pritchard, T.S.; McMiller, T.L.; Wei, P.; Pardoll, D.M.; Pan, F.; Topalian, S.L. Mechanisms regulating PD-L1 expression on tumor and immune cells. J. Immunother. Cancer 2019, 7, 1-12. [CrossRef]

181. Williams, J.B.; Li, S.; Higgs, E.F.; Cabanov, A.; Wang, X.; Huang, H.; Gajewski, T.F. Tumor heterogeneity and clonal cooperation influence the immune selection of IFN- $\gamma$-signaling mutant cancer cells. Nat. Commun. 2020, 11, 1-14. [CrossRef]

182. Mazel, M.; Jacot, W.; Pantel, K.; Bartkowiak, K.; Topart, D.; Cayrefourcq, L.; Rossille, D.; Maudelonde, T.; Fest, T.; Alix-Panabières, C. Frequent expression of PD-L1 on circulating breast cancer cells. Mol. Oncol. 2015, 9, 1773-1782. [CrossRef]

183. Schott, D.S.; Pizon, M.; Pachmann, U.; Pachmann, K. Sensitive detection of PD-L1 expression on circulating epithelial tumor cells (CETCs) could be a potential biomarker to select patients for treatment with PD-1/PD-L1 inhibitors in early and metastatic solid tumors. Oncotarget 2017, 8, 72755-72772. [CrossRef] [PubMed] 
184. Ilié, M.; Szafer-Glusman, E.; Hofman, V.; Chamorey, E.; Lalvée, S.; Selva, E.; Leroy, S.; Marquette, C.H.; Kowanetz, M.; Hedge, P.; et al. Detection of PD-L1 in circulating tumor cells and white blood cells from patients with advanced non-small-cell lung cancer. Ann. Oncol. 2018, 29, 193-199. [CrossRef] [PubMed]

185. Dong, J.; Zhu, D.; Tang, X.; Qiu, X.; Lu, D.; Li, B.; Lin, D.; Zhou, Q. Detection of circulating tumor cell molecular subtype in pulmonary vein predicting prognosis of stage i-iii non-small cell lung cancer patients. Front. Oncol. 2019, 9. [CrossRef] [PubMed]

186. Kloten, V.; Lampignano, R.; Krahn, T.; Schlange, T. Circulating Tumor Cell PD-L1 Expression as Biomarker for Therapeutic Efficacy of Immune Checkpoint Inhibition in NSCLC. Cells 2019, 8, 809. [CrossRef]

187. Zhong, X.; Zhang, H.; Zhu, Y.; Liang, Y.; Yuan, Z.; Li, J.; Li, J.; Li, X.; Jia, Y.; He, T.; et al. Circulating tumor cells in cancer patients: Developments and clinical applications for immunotherapy. Mol. Cancer 2020, 19, 1-12. [CrossRef]

188. Manjunath, Y.; Upparahalli, S.V.; Avella, D.M.; Deroche, C.B.; Kimchi, E.T.; Staveley-O'carroll, K.F.; Smith, C.J.; Li, G.; Kaifi, J.T. PD-L1 expression with epithelial mesenchymal transition of circulating tumor cells is associated with poor survival in curatively resected non-small cell lung cancer. Cancers 2019, 11, 806. [CrossRef] [PubMed]

189. Miao, Y.; Yang, H.; Levorse, J.; Yuan, S.; Polak, L.; Sribour, M.; Singh, B.; Rosenblum, M.D.; Fuchs, E. Adaptive Immune Resistance Emerges from Tumor-Initiating Stem Cells. Cell 2019, 177, 1172-1186.e14. [CrossRef]

190. Mu, Z.; Benali-Furet, N.; Uzan, G.; Znaty, A.; Ye, Z.; Paolillo, C.; Wang, C.; Austin, L.; Rossi, G.; Fortina, P.; et al. Detection and characterization of circulating tumor associated cells in metastatic breast cancer. Int. J. Mol. Sci. 2016, 17, 1665. [CrossRef]

191. Tucci, M.; D’Oronzo, S.; Mannavola, F.; Felici, C.; Lovero, D.; Cafforio, P.; Palmirotta, R.; Silvestris, F. Dual-procedural separation of CTCs in cutaneous melanoma provides useful information for both molecular diagnosis and prognosis. Ther. Adv. Med. Oncol. 2020, 12, 1-14. [CrossRef]

192. Zeinali, M.; Lee, M.; Nadhan, A.; Mathur, A.; Hedman, C.; Lin, E.; Harouaka, R.; Wicha, M.S.; Zhao, L.; Palanisamy, N.; et al. High-throughput label-free isolation of heterogeneous circulating tumor cells and CTC clusters from non-small-cell lung cancer patients. Cancers 2020, 12, 127. [CrossRef]

193. Brechbuhl, H.M.; Vinod-Paul, K.; Gillen, A.E.; Kopin, E.G.; Gibney, K.; Elias, A.D.; Hayashi, M.; Sartorius, C.A.; Kabos, P. Analysis of circulating breast cancer cell heterogeneity and interactions with peripheral blood mononuclear cells. Mol. Carcinog. 2020, 59, 1129-1139. [CrossRef]

194. Ramani, V.C.; Lemaire, C.A.; Triboulet, M.; Casey, K.M.; Heirich, K.; Renier, C.; Vilches-Moure, J.G.; Gupta, R.; Razmara, A.M.; Zhang, H.; et al. Investigating circulating tumor cells and distant metastases in patient-derived orthotopic xenograft models of triple-negative breast cancer. Breast Cancer Res. 2019, 21, 1-16. [CrossRef]

195. Balakrishnan, A.; Koppaka, D.; Anand, A.; Deb, B.; Grenci, G.; Viasnoff, V.; Thompson, E.W.; Gowda, H.; Bhat, R.; Rangarajan, A.; et al. Circulating Tumor Cell cluster phenotype allows monitoring response to treatment and predicts survival. Sci. Rep. 2019, 9, 1-8. [CrossRef]

196. Tarazona, N.; Gimeno-Valiente, F.; Gambardella, V.; Zuñiga, S.; Rentero-Garrido, P.; Huerta, M.; Roselló, S.; Martinez-Ciarpaglini, C.; Carbonell-Asins, J.A.; Carrasco, F.; et al. Targeted next-generation sequencing of circulating-tumor DNA for tracking minimal residual disease in localized colon cancer. Ann. Oncol. 2019, 30, 1804-1812. [CrossRef]

197. Tarazona, N.; Gimeno-Valiente, F.; Gambardella, V.; Huerta, M.; Roselló, S.; Zuniga, S.; Calon, A.; Carbonell-Asins, J.A.; Fontana, E.; Martinez-Ciarpaglini, C.; et al. Detection of postoperative plasma circulating tumour DNA and lack of CDX2 expression as markers of recurrence in patients with localised colon cancer. ESMO Open 2020, 5, 1-7. [CrossRef]

198. André, P.; Denis, C.; Soulas, C.; Bourbon-Caillet, C.; Lopez, J.; Arnoux, T.; Bléry, M.; Bonnafous, C.; Gauthier, L.; Morel, A.; et al. Anti-NKG2A mAb Is a Checkpoint Inhibitor that Promotes Anti-tumor Immunity by Unleashing Both T and NK Cells. Cell 2018, 175, 1731-1743.e13. [CrossRef]

199. Robert, C.; Ribas, A.; Hamid, O.; Daud, A.; Wolchok, J.D.; Joshua, A.M.; Hwu, W.J.; Weber, J.S.; Gangadhar, T.C.; Joseph, R.W.; et al. Durable complete response after discontinuation of pembrolizumab in patients with metastatic melanoma. J. Clin. Oncol. 2018, 36, 1668-1674. [CrossRef]

200. Van Montfoort, N.; Borst, L.; Korrer, M.J.; Sluijter, M.; Marijt, K.A.; Santegoets, S.J.; van Ham, V.J.; Ehsan, I.; Charoentong, P.; André, P.; et al. NKG2A Blockade Potentiates CD8 T Cell Immunity Induced by Cancer Vaccines. Cell 2018, 175, 1744-1755.e15. [CrossRef]

201. Kurtulus, S.; Madi, A.; Escobar, G.; Klapholz, M.; Nyman, J.; Christian, E.; Pawlak, M.; Dionne, D.; Xia, J.; Rozenblatt-Rosen, O.; et al. Checkpoint Blockade Immunotherapy Induces Dynamic Changes in PD-1 - CD8 + Tumor-Infiltrating T Cells. Immunity 2019, 50, 181-194.e6. [CrossRef]

202. Larkin, J.; Chiarion-Sileni, V.; Gonzalez, R.; Grob, J.-J.; Rutkowski, P.; Lao, C.D.; Cowey, C.L.; Schadendorf, D.; Wagstaff, J.; Dummer, R.; et al. Five-Year Survival with Combined Nivolumab and Ipilimumab in Advanced Melanoma. N. Engl. J. Med. 2019, 381, 1535-1546. [CrossRef]

203. Peggs, K.S.; Quezada, S.A.; Chambers, C.A.; Korman, A.J.; Allison, J.P. Blockade of CTLA-4 on both effector and regulatory T cell compartments contributes to the antitumor activity of anti-CTLA-4 antibodies. J. Exp. Med. 2009, 206, 1717-1725. [CrossRef] [PubMed]

204. Drake, C.G.; Lipson, E.J.; Brahmer, J.R. Breathing new life into immunotherapy: Review of melanoma, lung and kidney cancer. Nat. Rev. Clin. Oncol. 2014, 11, 24-37. [CrossRef] [PubMed]

205. Galon, J.; Bruni, D. Approaches to treat immune hot, altered and cold tumours with combination immunotherapies. Nat. Rev. Drug Discov. 2019, 18, 197-218. [CrossRef] 
206. Mariathasan, S.; Turley, S.J.; Nickles, D.; Castiglioni, A.; Yuen, K.; Wang, Y.; Kadel, E.E.; Koeppen, H.; Astarita, J.L.; Cubas, R.; et al. TGF $\beta$ attenuates tumour response to PD-L1 blockade by contributing to exclusion of T cells. Nature 2018, 554, 544-548. [CrossRef] [PubMed]

207. Cornen, S.; Vivier, E. Chemotherapy and tumor immunity. Science 2018, 362, 1355-1356. [CrossRef] [PubMed]

208. Bonaventura, P.; Shekarian, T.; Alcazer, V.; Valladeau-Guilemond, J.; Valsesia-Wittmann, S.; Amigorena, S.; Caux, C.; Depil, S. Cold tumors: A therapeutic challenge for immunotherapy. Front. Immunol. 2019, 10, 1-10. [CrossRef] [PubMed]

209. Ribas, A.; Lawrence, D.; Atkinson, V.; Agarwal, S.; Miller, W.H.; Carlino, M.S.; Fisher, R.; Long, G.V.; Hodi, F.S.; Tsoi, J.; et al. Combined BRAF and MEK inhibition with PD-1 blockade immunotherapy in BRAF-mutant melanoma. Nat. Med. 2019, 25, 936-940. [CrossRef]

210. Galsky, M.D.; Arija, J.Á.A.; Bamias, A.; Davis, I.D.; De Santis, M.; Kikuchi, E.; Garcia-del-Muro, X.; De Giorgi, U.; Mencinger, M.; Izumi, K.; et al. Atezolizumab with or without chemotherapy in metastatic urothelial cancer (IMvigor130): A multicentre, randomised, placebo-controlled phase 3 trial. Lancet 2020, 395, 1547-1557. [CrossRef]

211. Galsky, M.D.; Mortazavi, A.; Milowsky, M.I.; George, S.; Gupta, S.; Fleming, M.T.; Dang, L.H.; Geynisman, D.M.; Walling, R.; Alter, R.S.; et al. Randomized Double-Blind Phase II Study of Maintenance Pembrolizumab Versus Placebo after First-Line Chemotherapy in Patients with Metastatic Urothelial Cancer. J. Clin. Oncol. 2020, 38, 1797-1806. [CrossRef]

212. Gnjatic, S.; Bronte, V.; Brunet, L.R.; Butler, M.O.; Disis, M.L.; Galon, J.; Hakansson, L.G.; Hanks, B.A.; Karanikas, V.; Khleif, S.N.; et al. Identifying baseline immune-related biomarkers to predict clinical outcome of immunotherapy. J. Immunother. Cancer 2017, 5, 1-18. [CrossRef]

213. Le, D.T.; Uram, J.N.; Wang, H.; Bartlett, B.R.; Kemberling, H.; Eyring, A.D.; Skora, A.D.; Luber, B.S.; Azad, N.S.; Laheru, D.; et al. PD-1 Blockade in Tumors with Mismatch-Repair Deficiency. N. Engl. J. Med. 2015, 372, 2509-2520. [CrossRef] [PubMed]

214. Galon, J.; Costes, A.; Sanchez-Cabo, F.; Kirilovsky, A.; Mlecnik, B.; Lagorce-Pagès, C.; Tosolini, M.; Camus, M.; Berger, A.; Wind, P.; et al. Type, density, and location of immune cells within human colorectal tumors predict clinical outcome. Science (80-.) 2006, 313, 1960-1964. [CrossRef] [PubMed]

215. Barnes, T.A.; Amir, E. HYPE or HOPE: The prognostic value of infiltrating immune cells in cancer. Br. J. Cancer 2017, 117, 451-460. [CrossRef] [PubMed]

216. Carstens, J.L.; De Sampaio, P.C.; Yang, D.; Barua, S.; Wang, H.; Rao, A.; Allison, J.P.; Le Bleu, V.S.; Kalluri, R. Spatial computation of intratumoral T cells correlates with survival of patients with pancreatic cancer. Nat. Commun. 2017, 8. [CrossRef] [PubMed]

217. Jiménez-Sánchez, A.; Memon, D.; Pourpe, S.; Veeraraghavan, H.; Li, Y.; Vargas, H.A.; Gill, M.B.; Park, K.J.; Zivanovic, O.; Konner, J.; et al. Heterogeneous Tumor-Immune Microenvironments among Differentially Growing Metastases in an Ovarian Cancer Patient. Cell 2017, 170, 927-938.e20. [CrossRef] [PubMed]

218. Uryvaev, A.; Passhak, M.; Hershkovits, D.; Sabo, E.; Bar-Sela, G. The role of tumor-infiltrating lymphocytes (TILs) as a predictive biomarker of response to anti-PD1 therapy in patients with metastatic non-small cell lung cancer or metastatic melanoma. Med. Oncol. 2018, 35, 1-9. [CrossRef]

219. Van den Eynde, M.; Mlecnik, B.; Bindea, G.; Fredriksen, T.; Church, S.E.; Lafontaine, L.; Haicheur, N.; Marliot, F.; Angelova, M.; Vasaturo, A.; et al. The Link between the Multiverse of Immune Microenvironments in Metastases and the Survival of Colorectal Cancer Patients. Cancer Cell 2018, 34, 1012-1026.e3. [CrossRef]

220. Bruni, D.; Angell, H.K.; Galon, J. The immune contexture and Immunoscore in cancer prognosis and therapeutic efficacy. Nat. Rev. Cancer 2020, 20, 662-680. [CrossRef]

221. Yost, K.E.; Satpathy, A.T.; Wells, D.K.; Qi, Y.; Wang, C.; Kageyama, R.; McNamara, K.L.; Granja, J.M.; Sarin, K.Y.; Brown, R.A.; et al. Clonal replacement of tumor-specific T cells following PD-1 blockade. Nat. Med. 2019, 25, 1251-1259. [CrossRef]

222. Cloughesy, T.F.; Mochizuki, A.Y.; Orpilla, J.R.; Hugo, W.; Lee, A.H.; Davidson, T.B.; Wang, A.C.; Ellingson, B.M.; Rytlewski, J.A.; Sanders, C.M.; et al. Neoadjuvant anti-PD-1 immunotherapy promotes a survival benefit with intratumoral and systemic immune responses in recurrent glioblastoma. Nat. Med. 2019, 25, 477-486. [CrossRef]

223. Fairfax, B.P.; Taylor, C.A.; Watson, R.A.; Nassiri, I.; Danielli, S.; Fang, H.; Mahé, E.A.; Cooper, R.; Woodcock, V.; Traill, Z.; et al. Peripheral CD8+ T cell characteristics associated with durable responses to immune checkpoint blockade in patients with metastatic melanoma. Nat. Med. 2020, 26, 193-199. [CrossRef]

224. Valpione, S.; Galvani, E.; Tweedy, J.; Mundra, P.A.; Banyard, A.; Middlehurst, P.; Barry, J.; Mills, S.; Salih, Z.; Weightman, J.; et al. Immune awakening revealed by peripheral T cell dynamics after one cycle of immunotherapy. Nat. Cancer 2020, 1, $210-221$. [CrossRef]

225. Wu, T.D.; Madireddi, S.; de Almeida, P.E.; Banchereau, R.; Chen, Y.J.J.; Chitre, A.S.; Chiang, E.Y.; Iftikhar, H.; O'Gorman, W.E.; Au-Yeung, A.; et al. Peripheral T cell expansion predicts tumour infiltration and clinical response. Nature 2020, 579, $274-278$. [CrossRef] [PubMed]

226. Zhang, L.; Yu, X.; Zheng, L.; Zhang, Y.; Li, Y.; Fang, Q.; Gao, R.; Kang, B.; Zhang, Q.; Huang, J.Y.; et al. Lineage tracking reveals dynamic relationships of T cells in colorectal cancer. Nature 2018, 564, 268-272. [CrossRef] [PubMed] 